\title{
Effects of dietary polyunsaturated fatty acids on the composition of the individual lipids of turkey breast and leg muscle
}

\author{
By T. S. NEUDOERFFER AND C. H. LEA \\ Agricultural Research Council, Food Research Institute, \\ Low Temperature Research Station, Cambridge \\ (Received 4 Fanuary 1967-Accepted 24 February 1967)
}

\begin{abstract}
x. Groups of turkeys were given, to ro weeks of age: diets E, basal, containing $2 \cdot 3 \%$ mainly cereal lipid; A, basal plus $2.5 \%$ beef fat; B, basal plus $2.5 \%$ anchovy oil; C, as B, plus $0.02 \%$ ethoxyquin; D, basal plus $5 \%$ anchovy oil. Lipids from breast and leg muscle of all five groups were fractionated by thin-layer chromatography into five 'neutral' and six phospholipid fractions and the fatty-acid composition of each was determined by gas-liquid chromatography.

2. Individual lipid fractions differed widely in fatty-acid composition and in the degree to which they could be influenced by dietary fat supplements. Small but usually consistent differences were observed between corresponding fractions from breast and leg. Sphingomyelin (SP) and lysophosphatidylcholine contained largely saturated acids (76-80\%); the other phospholipids were $44-48 \%$ and the 'neutral' lipids $38-50 \%$ saturated. Phosphatidylserine (PS), phosphatidylinositol (PI) and, in less degree, phosphatidylethanolamine (PE) were rich in stearic acid, though palmitic was much more abundant in the diets and in the other muscle lipids. SP contained no acid more unsaturated than linoleic $(\mathbf{I}-2 \%)$. PE and PI were richest in arachidonic and $\mathrm{PE}$ and $\mathrm{PI}$ in other polyene acids.

3. The effects of beef fat on the muscle lipids were small and mainly on the 'neutral' fractions.

4. The polyunsaturated fatty acids of the fish oil extensively displaced linoleic (and oleic) acids from all fractions (except SP); arachidonic acid was displaced from PE but not from PI.

5. The degree to which the fish-oil polyunsaturated acids of the three series entered the muscle lipids varied with the acid and with the fraction. Docosahexaenoic acid $(22: 6)$ reached a concentration of $20-25 \%$ in $\mathrm{PE}$, nearly five times as great as its concentration in the dietary lipid.

6. Hydrolysis with phospholipase A showed that most of the unsaturated fatty acids were present in the 2-position of $\mathrm{PC}$ and $\mathrm{PE}$, but the positional specificity was not complete, particularly for the less highly unsaturated acids.

7. The antioxidant ethoxyquin had no effect on the fatty-acid composition of any of the muscle lipid fractions.
\end{abstract}

It has been well established, e.g. by the work of Dam \& Søndergaard (1964) with linoleate and by Miller, Leong, Knobl \& Gruger (1964, 1965) with the more highly unsaturated fatty acids of fish oil, that the ingestion of polyunsaturated fatty acids can be detrimental to the health of chicks, unless sufficient quantities of vitamin $\mathrm{E}$ or other biologically active antioxidant are also given. The inclusion of highly unsaturated fat in the diet can also impart 'fishy' off-flavours to the cooked flesh (Lea, Parr, L'Estrange \& Carpenter I966; Fry, van Walleghem, Waldroup \& Harms, I965; Hardin, Milligan \& Sidwell, I964). Both of these phenomena, which were discussed at greater length in a previous paper (Neudoerffer \& Lea, rg66a) are likely to be due, in part at least, to the deposition of dietary fatty acids in the tissues of the body, a transference that has been substantiated by the work of, among others, Marion \& 
Woodroof (1963, 1966), Marion (1965), Leveille \& Sauberlich (1963, 1964), Machlin \& Gordon (196I) and Mickelberry, Rogler \& Stadelman (1966).

In a previous paper (Neudoerffer \& Lea, 1966a) the effects of a diet containing $2.5 \%$ or $5.0 \%$ fish oil on the nutrition of turkeys, and on the fatty-acid compositions and stabilities of the skin fats (virtually all triglycerides) were measured, by comparison with control birds receiving a diet containing $2.5 \%$ beef fat. It was found that the characteristic highly unsaturated fatty acids of the fish oil were laid down in the turkey depot fat roughly in proportion to their concentrations in the dietary lipid, except for acid 22:5 which reached two or three times the expected level.

In the present paper this work has been extended $(a)$ by analysis of the skin fats of two additional groups of birds receiving the basal diet without added fat or a replica of $\operatorname{diet}$ A (basal diet plus $2.5 \%$ beef fat), and $(b)$ by analysis of the fractionated lipids of the breast and leg muscles of all five groups of birds. In all, five 'neutral lipid' and six phospholipid fractions were separated from each batch of muscle and their fattyacid compositions determined. Striking differences were observed in the relationships between dietary fatty acids and the fatty-acid compositions of individual lipids of the muscle. Quantitative aspects of the extraction and fractionation of the lipid from the muscle will be considered in a subsequent publication.

\section{EXPERIMENTAL}

\section{Material and diets}

Muscle tissue used in this work was obtained from four groups (A-D) of female Io/20 strain Broad Breasted White turkeys, whose performance has already been described and whose skin fats were analysed (Neudoerffer \& Lea, I $966 a$ ).

The isocaloric diets given to these birds were made up as follows.

Diet A: 92 parts basal diet, 2.5 parts beef fat and 5.5 parts maize starch.

Diet B: 92 parts basal diet, 2.5 parts anchovy oil and 5.5 parts maize starch.

Diet $\mathrm{C}$ : as $\operatorname{diet} \mathrm{B}$, but with the addition of $0.02 \%$ antioxidant, ethoxyquin (EMQ; 1,2-dihydro-6-ethoxy-2,2,4-trimethylquinoline).

Diet D: 92 parts basal diet, 5 parts anchovy oil and 3 parts cellulose powder. The supplementary vitamin $\mathrm{E}$ content of this diet was raised from 13 to $26 \mathrm{i} . \mathrm{u} . / \mathrm{kg}$ by doubling the amount of Rovimix E (Roche Products Ltd) added.

In addition, two further groups of three female Io/30 strain Broad Breasted White turkeys (Norfolk Manor Farms, Norwich) were raised. One group (A I) received diet A ( $2.5 \%$ beef fat), except for a partial replacement of maize starch by cellulose to make it isocaloric with a new diet $(\mathrm{E})$, which consisted of 92 parts basal diet and 8 parts maize, without any added oil or fat. The birds received these diets for 10 weeks, with a small additional protein supplement for the first 2. After slaughter, the tissues from the birds on each treatment were pooled and representative samples taken for analysis. 


\section{Extraction of the lipid}

Minced breast or leg muscle $(25 \mathrm{~g})$ was freeze-dried to a water content of $<4 \%$ and extracted for $\mathrm{I} h$ in darkness, under nitrogen, in a hot extraction apparatus with de-aerated chloroform-methanol $(2: \mathrm{I}, \mathrm{v} / \mathrm{v}, 200 \mathrm{ml})$ containing about $5 \mathrm{mg}$ of quinol. The extract was then transferred to a $500 \mathrm{ml}$ centrifuge cup, its volume was made up to $240 \mathrm{ml}$ and $0.9 \% \mathrm{NaCl}(60 \mathrm{ml})$ was added (Winter, 1963$)$. After stirring for $\mathrm{I}$ min the two phases were separated by centrifugation at $\mathrm{I}^{\circ}$. It was found that cooling the mixture to $-20^{\circ}$ and recentrifugation helped to remove residual traces of lipoprotein. One hundred $\mathrm{ml}$ of the lower phase (total volume, $175 \mathrm{ml}$ at $20^{\circ}$ ) were evaporated to dryness and the residual lipid was taken up in a known volume of chloroformmethanol $(2: \mathrm{I}, \mathrm{v} / \mathrm{v})$ containing $5 \mathrm{mg}$ 2,6-di-tertbutyl-4-methylphenol (butylated hydroxy toluene; $\mathrm{BHT}) / \mathrm{ro0} \mathrm{ml}$ and stored in a refrigerator over solid $\mathrm{CO}_{2}$ at $-60^{\circ}$ to $-70^{\circ}$.

\section{Thin-layer chromatography}

Preliminary separation of the total extractable lipids into 'neutral' lipid and phospholipid fractions by column chromatography was considered inadvisable because of the difficulty of avoiding autoxidation by dissolved and adsorbed oxygen of highly unsaturated lipid fractions (Lea, 1956), some of which in the present work had iodine values as high as 200 . Instead, rapid fractionation on preparative $(40 \mathrm{~cm})$ thin-layer plates at $\mathrm{I}^{\circ}$ was preferred, additional protection being provided by the addition of an antioxidant to the solvent used for development (Neudoerffer \& Lea, I966b).

Silica-gel H (Merck, Darmstadt) was purified as suggested by Parker \& Peterson ( 1965$)$. A slurry of silica gel $(25 \mathrm{~g})$ and water $(60 \mathrm{ml})$, or $0 \cdot 2 \mathrm{M}-\mathrm{Na}_{2} \mathrm{CO}_{3}$ solution (60 ml), was applied as a film of thickness $0.3 \mathrm{~mm}$ to the plates, which were then dried and activated at $110^{\circ}$. Development was in S-type tanks, consisting of a silicic acidcoated plate and glass cover, separated on three sides by a peripheral spacer cut from a sheet of $\mathrm{I} \mathrm{cm}$ alkathene, the open side of the tank being immersed in solvent. Use of a saturation chamber (Parker \& Peterson, 1965) was avoided by moistening a sheet of filter-paper inside the tank with solvent immediately before development. Lipid solution was applied to the chromatoplates as a line 2-3 $\mathrm{mm}$ wide, $2 \mathrm{~cm}$ from the bottom of the plate. The mechanical applicator used was adapted from that described by McKibbins, Harris \& Saeman (1961), to make it suitable for thin-layer chromatography plates, by bending the syringe needle at an angle of $90^{\circ}$ into a vertical position in relation to the horizontal barrel of the syringe. With plates positioned $3-5 \mathrm{~mm}$ below the end of the needle a slow, continuous movement of the syringe carriage gave uniform application without damage to the surface. After loading with $12-15 \mathrm{mg}$ total lipid the plates were divided into $4 \mathrm{~cm}$ lanes and developed in a constant temperature room at $\mathrm{I}^{\circ}$.

Two solvent mixtures were used, one fractionating the neutral lipids and leaving the phospholipids at the point of application, the other depositing the neutral lipids at the solvent front and fractionating the phospholipids. This procedure had the slight limitation of not permitting the separation of two very minor fractions, namely 
cardiolipin fraction and monoglycerides, which remained respectively within the unresolved neutral lipids and phospholipids. Otherwise, no difficulties of resolution were encountered.

Though the solvent mixture used for development usually contained an antioxidant, preferably monobutyl quinol (MBQ; Neudoerffer \& Lea, I966b), it was found that on gas chromatography of the fatty-acid methyl esters from minor lipid fractions a peak derived from this antioxidant became detectable in the $\mathrm{C}_{17}-\mathrm{C}_{18}$ region on the polyethyleneglycol adipate (PEGA) columns. In such instances BHT was preferred because its peak, at about $\mathrm{C}_{12}$, was less likely to be confused with methyl esters. Similarly, two small peaks in the $\mathrm{C}_{15}-\mathrm{C}_{16}$ and $\mathrm{C}_{16}-\mathrm{C}_{17}$ regions, derived from quinol used during the methylation process (below), could become detectable among the fatty-acid methyl esters from minor lipid fractions. When this happened the antioxidant was used at a lower concentration or omitted entirely.

The solvent used to resolve the neutral lipids was hexane-diethyl ether-acetic acid (79:20:I), a modification of that used by Malins \& Mangold (1960). Five lipid bands were separated and identified by comparison with reference compounds as cholesterol esters (CE), triglycerides (TG), free fatty acids (FFA) and diglycerides (DG). The fifth band, which ran between TG and FFA and contained combined fatty acids, could not be identified with any available reference compound and will be referred to as unknown lipid ' $X$ '. The diglyceride fraction clearly contained members of both the I,3 and I,2 series, but they ran close together and no attempt was made to separate them; a little free cholesterol was also present in this fraction. Cholesterol esters and the unknown lipid were present only in trace amounts. It was found that pure cholesterol-ester fractions could only be obtained if the plates used for chromatography of the neutral lipids were washed with solvent, dried and reactivated before use.

For separation of the phospholipids, the chloroform-methanol-acetic acid-water (25: $5: 4: 2$ ) system of Skipski, Peterson \& Barclay (1962, 1964) or a slight modification thereof $(25: 14: 4: 2)$, was used. The phospholipids separated into six bands, identified by standard procedures and by comparison with standard reference compounds (Applied Science Laboratories Inc., State College, $\mathrm{Pa}$ ) as phosphatidylethanolamine (PE), phosphatidylserine (PS), phosphatidylinositol (PI), phosphatidylcholine (PC), sphingomyelin (SP) and lysophosphatidylcholine (LPC), the last being present only in trace amounts.

\section{Methylation and gas-liquid chromatography $(G L C)$}

Developed plates were dried in the $\mathrm{I}^{\circ}$ room in a stream of warmed nitrogen and sprayed with rhodamine-fluorescein (Neudoerffer \& Lea, I966a). After outlining the separated bands under the ultraviolet lamp $(325 \mathrm{~nm})$ areas of silica gel carrying lipid were separately transferred to small flasks for methylation. Methylation in presence of the silica gel and recovery of the methyl ester and dimethyl acetal end-products were carried out as described by Bowyer, Leat, Howard \& Gresham (1963), except that the reaction time for fractions other than sphingomyelin was increased from $\mathrm{r}$ to $\mathrm{r} \cdot 5 \mathrm{~h}$. To ensure complete conversion of plasmalogen aldehydes into dimethyl acetals it was found necessary to increase the ratio of methanol-sulphuric acid to lipid above that 
suggested by Bowyer et al. (Neudoerffer, in preparation). The recovered methyl ester-dimethyl acetal mixtures were held over solid $\mathrm{CO}_{2}$ at $-60^{\circ}$ to $-70^{\circ}$ until analysed by temperature programmed gas-liquid chromatography, as previously described (Neudoerffer \& Lea, I966a).

\section{Differentiation between dimethyl acetals and methyl esters}

After gas-chromatographic analysis of the acetal-ester mixtures the esters in a further sample of each mixture were destroyed by saponification, followed by recovery and re-chromatography of the alkali-resistant acetals, according to the procedure of O’Brien, Fillerup \& Mead (1964).

\section{Partial hydrolysis of phospholipid fractions by phospholipase $A$}

The phosphatidylcholine and phosphatidylethanolamine bands were scraped from the plates and the lipid eluted from the silica gel by extraction with three $5 \mathrm{ml}$ portions of the development solvent. The solvent was then removed and the lipid redissolved in diethyl ether for treatment with Crotalus adamanteus venom, under the conditions defined by Menzel \& Olcott (I964). At the end of the reaction period the ether was distilled off and the residual lipid dissolved in a small volume of chloroform-methanol $(\mathrm{r}: \mathrm{I}, \mathrm{v} / \mathrm{V}$ ) for application to chromatoplates and development with solvent of the composition previously used for separation of the phospholipids. The separated free fatty acid, lysophospholipid and unchanged phospholipid (if any) fractions were then methylated and analysed by GLC as described above.

\section{RESULTS}

To facilitate comparison of the fatty-acid compositions of the numerous lipids analysed in this paper tables have been divided into (a) major constituents, comprising $>2 \%$, and $(b)$ minor constituents, comprising $<2 \%$ of the total acids. Values for a few acids occurring only in traces have been omitted.

\section{Composition of the skin lipids}

The fatty-acid compositions of the skin lipids (essentially triglycerides) of turkeys receiving the two additional diets $\left(\mathrm{A}_{\mathrm{I}}\right.$ and $\mathrm{E}$ ) are given in Table $\mathrm{I}$, together with the corresponding values for diet $A$ : values for the other diets have already been reported (Neudoerffer \& Lea, 1966a). There was very little difference between the fatty-acid patterns of the depot fats laid down by the groups of birds (A and A I) receiving the diet supplemented with beef fat in the two experiments, despite slight differences in strain and in the total calorific value of the diets.

The main effects of the inclusion of beef fat in the diet on the fatty-acid composition of the turkey depot fat were increases (to nearly double) in the oleic to palmitoleic and stearic to palmitic acid ratios, attributable to the high contents of oleic and stearic acids in the beef fat. The reduction in linoleic acid content was surprisingly small in view of the high content of this acid in the lipids of the basal diet $(43.2 \%)$ and its very low concentration $(2.9 \%)$ in the beef fat. 
Table I. Fatty-acid compositions (wt \%) of the skin lipids of turkeys receiving basal diet or basal diet plus $2.5 \%$ beef fat

\begin{tabular}{|c|c|c|c|}
\hline \multirow{3}{*}{$\begin{array}{l}\text { Probable } \\
\text { identity of } \\
\text { fatty acid }\end{array}$} & \multicolumn{3}{|c|}{ Skin lipids } \\
\hline & \multirow{2}{*}{$\begin{array}{c}\text { Basal diet } \\
\text { E }\end{array}$} & \multicolumn{2}{|c|}{ Basal diet $+2.5 \%$ beef fat } \\
\hline & & A I & $A *$ \\
\hline \multicolumn{4}{|c|}{ Major constituents $(>2 \%)$} \\
\hline $16: 0$ & 30.5 & $24 \cdot 6$ & $25^{\circ} \circ$ \\
\hline $16: 1$ & II. 6 & $7 \cdot 2$ & $7 \cdot 0$ \\
\hline $18: 0$ & $6 \cdot 0$ & $9 \cdot 9$ & 10.3 \\
\hline $18: \mathrm{I}$ & $32 \cdot 6$ & $38 \cdot 8$ & $37-4$ \\
\hline $18: 2$ & $14 \cdot 8$ & $12 \cdot 9$ & 13.9 \\
\hline \multicolumn{4}{|c|}{ Minor constituents $(<2 \%)$} \\
\hline 14:0 & $1 \cdot 0$ & $I \cdot 6$ & $1 \cdot 7$ \\
\hline $14: 1$ & 0.4 & 0.5 & 0.5 \\
\hline I 5:0 & 0.3 & 0.4 & 0.3 \\
\hline $17: 0$ & $1 \cdot 0$ & $\mathbf{x} \cdot \dot{6}$ & 0.7 \\
\hline $17: 1,18$ br & - & 0.6 & 0.4 \\
\hline $18: 3$ & $I \cdot I$ & $\mathbf{I} \cdot 5$ & $I \cdot 3$ \\
\hline $20: 0$ & 一 & 一 & 0.5 \\
\hline $20: 1$ & 0.7 & 0.8 & 0.5 \\
\hline
\end{tabular}

Table 2. Fatty-acid compositions (wt \%) of the triglyceride fraction of the muscle lipids of turkeys receiving diets $E$ (control) and $A-D *$

\begin{tabular}{|c|c|c|c|c|c|c|c|c|c|c|}
\hline \multirow[b]{2}{*}{ Fatty acid } & \multicolumn{5}{|c|}{ Breast muscle } & \multicolumn{5}{|c|}{ Leg muscle } \\
\hline & $E$ & A & $\mathbf{B}$ & C & $D$ & $E$ & A & $B$ & $\mathrm{C}$ & D \\
\hline \multicolumn{11}{|c|}{ Major constituents (> $2 \%$ ) } \\
\hline $14: 0$ & $I \cdot O$ & $2 \cdot I$ & $4 \cdot I$ & $4 \cdot 7$ & $5 \cdot 7$ & $I \cdot I$ & $1 \cdot 5$ & $5 \cdot 0$ & $4 \%$ & 5.9 \\
\hline $16: 0$ & $29^{\prime} I$ & $23 \cdot 5$ & 24.0 & $24 \cdot 2$ & $2 I \cdot 9$ & 30.7 & $27 \cdot 3$ & $26 \cdot 1$ & $25 \cdot 2$ & $23 \cdot 2$ \\
\hline I6: I & II.5 & $6 \cdot 8$ & $7 \cdot 1$ & $6 \cdot 1$ & $7 \cdot 8$ & 10.2 & 6.7 & $6 \cdot I$ & $7 \cdot 7$ & 7.0 \\
\hline $18: 0$ & $6 \cdot 3$ & 10.5 & $9 \cdot I$ & 97 & $7 \cdot 8$ & $6 \cdot 2$ & $9 \cdot 8$ & $10 \cdot 6$ & $9 \cdot 5$ & $8 \cdot I$ \\
\hline 18:1 & $32 \cdot 9$ & $40 \cdot 0$ & $21 \cdot 0$ & $20 \cdot 6$ & $18 \cdot 9$ & $3 I \cdot 9$ & $3^{8 \cdot 1}$ & 20.0 & $19 \cdot 9$ & $19 \cdot 0$ \\
\hline I $8: 2$ & $15 \cdot 7$ & $14 \cdot 2$ & $15 \cdot 7$ & $16 \cdot 3$ & $12 \cdot 5$ & $16 \cdot 3$ & $13 \cdot 1$ & $15 \cdot 1$ & $16 \cdot 2$ & 12.7 \\
\hline $20: 5$ & - & - & $6 \cdot 5$ & $6 \cdot 5$ & $10 \cdot 0$ & - & - & $5 \cdot 8$ & $5 \cdot 8$ & 9.2 \\
\hline $22: 5 \omega_{3}$ & 一 & - & $2 \cdot 5$ & $2 \cdot 3$ & $3 \cdot 0$ & - & - & $2 \cdot 3$ & $2 \cdot 3$ & $3 \cdot 1$ \\
\hline $22: 6$ & - & - & $2 \cdot 0$ & $2 \cdot 0$ & $3 \cdot 8$ & 一 & - & $2 \cdot 2$ & $2 \cdot 2$ & 3.8 \\
\hline \multicolumn{11}{|c|}{ Minor constituents $(<2 \%)$} \\
\hline 12:0 & $I \cdot 4$ & $1 \cdot 0$ & 1.0 & $I \cdot O$ & $I \cdot 0$ & 0.3 & 0.5 & 0.5 & 0.5 & 0.6 \\
\hline I 5:0 & 0.3 & 0.5 & 0.5 & 0.5 & $0 \cdot 3$ & 0.7 & 0.5 & 0.5 & 0.5 & 0.6 \\
\hline $16: 2$ & - & - & 0.6 & 0.6 & I.O & - & - & 0.6 & 0.4 & $1 \cdot 0$ \\
\hline $16: 3$ & 一 & - & 0.7 & 0.6 & $I \cdot I$ & 一 & - & 0.3 & 0.5 & 0.9 \\
\hline $17: 0$ & $I \cdot O$ & 0.5 & 0.5 & 0.4 & 0.9 & 0.9 & 0.6 & 0.6 & 0.9 & 0.8 \\
\hline $18: 3$ & $I \cdot I$ & $\mathbf{I} \cdot \mathbf{2}$ & I. 9 & $I \cdot 5$ & $I \cdot 2$ & $I \cdot I$ & $I \cdot 2$ & $1 \cdot 6$ & $x \cdot 3$ & $r \cdot x$ \\
\hline I $8: 4$ & - & - & 0.7 & 0.6 & $I \cdot I$ & - & - & 0.6 & I.O & $\mathbf{I} \cdot \mathbf{I}$ \\
\hline 20: I & 0.3 & 0.3 & 0.8 & 0.4 & $\mathbf{I} \cdot \mathbf{I}$ & 0.4 & 0.4 & $\mathbf{I} \cdot \mathbf{I}$ & $I \cdot 0$ & I. 4 \\
\hline $20: 4$ & 0.4 & 一 & $1 \cdot 3$ & $1 \cdot 3$ & $I \cdot 0$ & - & - & 0.5 & $0 \cdot 6$ & 0.6 \\
\hline saturated & 38 & 38 & 39 & $4 I$ & $3^{8}$ & 40 & 40 & 43 & $4 \mathrm{I}$ & 39 \\
\hline nonoene & 45 & 47 & 29 & 27 & 28 & 43 & 45 & 27 & 29 & 27 \\
\hline diene & 16 & 14 & I6 & 17 & 13 & I6 & 13 & I6 & 17 & 14 \\
\hline polyene & $\mathbf{I}$ & I & I6 & I 5 & 21 & I & I & I 3 & 14 & 20 \\
\hline
\end{tabular}

* Details of the diets are given on p. 692 . 


\section{Composition of the muscle 'neutral' lipids}

Triglycerides. The fatty-acid compositions of the triglyceride fractions of the muscle lipids from breast and leg were very similar ('Table 2), and very similar also to the compositions previously reported for the depot (skin) lipids (Neudoerffer \& Lea I $966 a$ ). These observations are analogous to those of Marion \& Woodroof (I965) who found no appreciable difference between the fatty-acid compositions of triglycerides from skin, breast and leg tissues of broiler chickens.

Inclusion of beef fat, with its high content of stearic (18:0) and oleic (I8: I) acids in the diet markedly raised the stearic to palmitic and oleic to palmitoleic acid ratios in the muscle triglycerides, as it did in the skin triglycerides (Table I). In contrast, the linoleic acid contents were again only slightly depressed, despite the very low concentration of this acid in beef fat. Myristic acid ( $14: 0$ ), present in basal diet lipid, beef fat and anchovy oil at $\mathrm{I} \cdot \mathrm{I}, 3.5$ and $7.8 \%$ respectively, was deposited in increasing amounts in the muscle triglycerides of the birds receiving these diets.

Table 3. Compositions (wt \%) of the free fatty-acid fraction of the muscle lipids of turkeys receiving diets $E$ (control) and $A-D^{*}$

\begin{tabular}{|c|c|c|c|c|c|c|c|c|c|c|}
\hline \multirow[b]{2}{*}{ Fatty acid } & \multicolumn{5}{|c|}{ Breast muscle } & \multicolumn{5}{|c|}{ Leg muscle } \\
\hline & $\mathbf{E}$ & A & B & $\mathrm{C}$ & $\mathrm{D}$ & $\mathrm{E}$ & A & B & $\mathrm{C}$ & D \\
\hline \multicolumn{11}{|c|}{ Major constituents $(>2 \%)$} \\
\hline $14: 0$ & I.O & $\mathrm{I} \cdot 8$ & $1 \cdot 7$ & $x \cdot 8$ & $2 \cdot 0$ & $2 \cdot 0$ & $I \cdot 5$ & $2 \cdot 8$ & $\mathbf{I} \cdot 7$ & 40 \\
\hline $16: 0$ & $24^{\circ} 9$ & $22 \cdot 0$ & $25 \cdot 7$ & $25^{\circ} 4$ & $18 \cdot 7$ & $24 \cdot 2$ & $2 I \cdot 4$ & 20.9 & $19 \cdot 1$ & $20 \cdot 3$ \\
\hline I6:I & $7 \cdot 0$ & $4 \cdot 2$ & $2 \cdot 4$ & $2 \cdot 4$ & $4 \cdot 6$ & $7 \cdot 3$ & $6 \cdot 0$ & $6 \cdot 4$ & $5 \cdot 8$ & $6 \cdot 5$ \\
\hline I8:0 & II 3 & 14.9 & $17 \cdot 6$ & $17 \cdot 5$ & 13.5 & $9 \cdot 5$ & II 9 & $10 \cdot 1$ & 10.4 & $8 \cdot 4$ \\
\hline I8:I & 20.9 & $21 \cdot 4$ & 15.5 & 16.9 & 15.6 & 27.6 & 30.3 & $18 \cdot 3$ & 18.4 & $19 \cdot \mathbf{I}$ \\
\hline I $8: 2$ & $24 \cdot 4$ & $23 \cdot 8$ & $14 \cdot 5$ & $16 \cdot 2$ & 12.5 & $19 \cdot 9$ & $19 \cdot 1$ & I 8.8 & r9.3 & II.5 \\
\hline $20: 3 \omega 6$ & $2 \cdot 4$ & $I \cdot I$ & - & - & - & $2 \cdot 8$ & $\mathrm{I} \cdot 8$ & $\operatorname{Tr}$ & 0.5 & 0.4 \\
\hline $20: 4$ & 6.0 & $7 \cdot 7$ & $3 \cdot 2$ & $3 \cdot 6$ & 3.8 & 5.4 & $4 \cdot 2$ & $\mathrm{I} \cdot 9$ & $2 \cdot 5$ & $x \cdot 7$ \\
\hline $20: 5$ & 一 & 0.5 & $7 \cdot I$ & $6 \cdot 8$ & I 1 5 & - & I' 5 & $9 \cdot 4$ & $10 \cdot 0$ & II 3 \\
\hline $22: 5 \omega_{3}$ & 一 & $\operatorname{Tr}$ & $3 \cdot 4$ & $2 \cdot 4$ & $3 \cdot 3$ & - & 0.5 & $3 \cdot 3$ & $3 \cdot 3$ & $3 \cdot 2$ \\
\hline $22: 6$ & - & $\operatorname{Tr}$ & $5 \cdot 6$ & $5^{\cdot 1}$ & 9.0 & 一 & 0.5 & 43 & $4 \cdot 4$ & 8.0 \\
\hline \multicolumn{11}{|c|}{ Minor constituents $(<2 \%)$} \\
\hline 12:0 & 0.4 & 0.5 & 0.4 & 0.3 & 0.4 & 0.3 & 0.3 & 0.5 & 0.5 & 0.5 \\
\hline $15: 0$ & 0.4 & 0.5 & 0.7 & 0.4 & 0.6 & 0.4 & 0.3 & 0.5 & 0.5 & 0.5 \\
\hline $17: 0$ & - & 0.5 & 0.4 & 0.4 & 0.5 & - & 0.3 & 0.6 & 0.8 & 0.8 \\
\hline $16: 2$ & - & - & 0.4 & 0.4 & 0.6 & - & - & 0.4 & 0.6 & 0.9 \\
\hline $8: 3$ & $\mathrm{I} \cdot 3$ & $x \cdot 2$ & $1 \cdot 0$ & $1 \cdot 0$ & $I \cdot 2$ & 0.3 & 0.3 & 0.9 & 0.9 & 0.8 \\
\hline $18: 4$ & - & - & $\mathrm{Tr}$ & $\operatorname{Tr}$ & 0.5 & - & - & 0.3 & 0.3 & 0.4 \\
\hline $20: 1$ & 一 & - & $\operatorname{Tr}$ & $\operatorname{Tr}$ & 0.9 & 一 & - & 0.3 & 0.3 & 0.9 \\
\hline Total saturated & 38 & 40 & 46 & 46 & 36 & $3^{6}$ & 36 & 35 & 33 & 35 \\
\hline Total monoene & 28 & 26 & 18 & I9 & 21 & 35 & 36 & 25 & 25 & 27 \\
\hline Total diene & 24 & 24 & 15 & 17 & 13 & 20 & 19 & 19 & 20 & 12 \\
\hline Total polyene & IO & 10 & 20 & I9 & 29 & 9 & 9 & 20 & 22 & 26 \\
\hline
\end{tabular}

As with the skin lipids, the polyunsaturated fatty acids characteristic of the dietary fish oil (16:2, 16:3, 18:4, 20:4, 20:5, 22:5 and 22:6) appeared only in the muscle triglycerides of the birds receiving fish oil, whereas $20: \mathrm{I}$, already present in traces in 
the control birds, appeared in increased amount in the birds fed fish oil. Apart from acid $22: 5$, which was again incorporated into the triglycerides in unexpectedly large amount, there was no evidence of selective deposition of the fish-oil fatty acids, which appeared in the muscle triglycerides roughly in proportion to their concentrations in the dietary lipid.

Free fatty acids. Slight but consistent differences in composition between the free fatty-acid fractions from breast and leg muscle included higher $18: 0$ and 20:4 and lower I8: I contents in the former (Table 3 ).

Table 4. Fatty-acid compositions (wt \%) of the diglyceride fraction of the muscle lipids of turkeys receiving diets $E$ (control) and $A-D^{*}$

\begin{tabular}{|c|c|c|c|c|c|c|c|c|c|c|}
\hline \multirow[b]{2}{*}{ Fatty acid } & \multicolumn{5}{|c|}{ Breast muscle } & \multicolumn{5}{|c|}{ Leg muscle } \\
\hline & $\mathbf{E}$ & $\mathrm{A}$ & $\mathbf{B}$ & $\mathrm{C}$ & $\mathrm{D}$ & $\mathrm{E}$ & A & B & $\mathrm{C}$ & D \\
\hline \multicolumn{11}{|c|}{ Major constituents $(>2 \%)$} \\
\hline $14: 0$ & $\mathbf{I} \cdot 8$ & $2 \cdot 0$ & $2 \cdot 0$ & $2 \cdot I$ & $2 \cdot 2$ & I. 8 & $x \cdot 6$ & $2 \cdot 0$ & $1 \cdot 9$ & $2 \cdot 7$ \\
\hline 16:A & $3 \cdot 0$ & $2 \cdot 6$ & $2 \cdot 9$ & $2 \cdot 0$ & $2 \cdot 7$ & $3 \cdot 6$ & $2: 4$ & $2 \cdot 5$ & $2 \cdot 7$ & $2 \cdot 9$ \\
\hline $16: 0$ & $29^{\circ} \mathrm{I}$ & $29 \cdot 8$ & $27 \cdot 0$ & $27 \cdot 8$ & $27 \cdot 5$ & $20 \cdot 6$ & $20 \cdot 2$ & $20 \cdot 2$ & $21 \cdot 6$ & $20 \cdot 3$ \\
\hline $16: 1$ & $7 \cdot 8$ & $6 \cdot 0$ & $4 \cdot 0$ & $4^{\cdot I}$ & $3 \cdot 0$ & $6 \cdot 6$ & $4 \cdot 5$ & $4 \cdot 9$ & 4.5 & 4.0 \\
\hline $17: 0$ & 0.6 & 3.0 & $3 \cdot 7$ & $3 \cdot 4$ & $2 \cdot 1$ & 0.4 & $2 \cdot I$ & $2 \cdot 3$ & $1 \cdot 0$ & $2 \cdot 5$ \\
\hline $18: 0$ & $11 \cdot 7$ & $1 \times \cdot 0$ & I0. 8 & $I I \cdot I$ & $10 \cdot 6$ & IO. 1 & $9 \cdot 8$ & $8 \cdot 9$ & $9 \cdot 0$ & $8 \cdot 2$ \\
\hline 18:1 & $24 \cdot 3$ & $25 \cdot I$ & $20 \cdot 3$ & 20.4 & $18 \cdot 3$ & $28 \cdot 1$ & $31 \cdot 8$ & $26 \cdot 0$ & $24 \cdot 6$ & $20 \cdot 7$ \\
\hline $18: 2$ & $12 \cdot 4$ & $9 \cdot 5$ & $6 \cdot 0$ & $6 \cdot 1$ & $5 \cdot 4$ & $18 \cdot 2$ & 15.5 & 13.8 & 134 & II 4 \\
\hline I $8: 3$ & $I \cdot 7$ & $x \cdot 7$ & $2 \cdot I$ & $2 \cdot 2$ & $2 \cdot 5$ & I. 8 & I. 4 & $I \cdot I$ & 0.9 & $I \cdot O$ \\
\hline $20: 3 \omega 6$ & $\mathbf{I} \cdot 9$ & $1 \cdot 3$ & 0.9 & $\mathbf{I} \cdot \mathbf{I}$ & 0.9 & $2 \cdot 5$ & $1 \cdot 9$ & $r \cdot 3$ & 0.9 & $\mathrm{I} \cdot 2$ \\
\hline $20: 4$ & $4 \cdot 4$ & $4 \cdot \mathrm{I}$ & $2 \cdot 4$ & $2 \cdot 3$ & $2 \cdot 0$ & $4 \cdot 3$ & $3 \cdot 8$ & $2 \cdot 1$ & $2 \cdot 3$ & $2 \cdot 0$ \\
\hline $20: 5$ & - & I.O & $6 \cdot 0$ & $5 \cdot 9$ & $7 \cdot 0$ & $\mathrm{Tr}$ & $1 \cdot 7$ & $4 \cdot 3$ & 5.0 & $7 \cdot 6$ \\
\hline $22: 5 \omega_{3}$ & - & - & $3 \cdot 5$ & $3 \cdot 6$ & $3 \cdot 7$ & - & $\operatorname{Tr}$ & $2 \cdot 9$ & $2 \cdot 8$ & $3 \cdot 2$ \\
\hline $22: 6$ & - & - & 5.0 & 4.9 & $6 \cdot 0$ & $\longrightarrow$ & $\operatorname{Tr}$ & $4 \cdot I$ & 42 & $7 \cdot 0$ \\
\hline \multicolumn{11}{|c|}{ Minor constituents $(<2 \%)$} \\
\hline$I 2: 0$ & 0.6 & $r \cdot 0$ & $I \cdot 0$ & $1 \cdot 0$ & I'3 & 0.9 & 0.6 & $I \cdot O$ & 0.9 & $I \cdot O$ \\
\hline I $5: 0$ & 0.9 & $x \cdot 6$ & $I \cdot 7$ & $x \cdot 5$ & 0.8 & 0.9 & 0.7 & I.O & 0.9 & 0.9 \\
\hline$x 6: 2$ & - & 一 & $0: 4$ & 0.3 & 0.6 & - & - & $\mathrm{Tr}$ & $\mathrm{Tr}$ & $\operatorname{Tr}$ \\
\hline I $8: 4$ & - & - & $\operatorname{Tr}$ & $\operatorname{Tr}$ & $\mathrm{I} \cdot 4$ & - & - & 0.9 & 0.9 & $\mathrm{I} \cdot 7$ \\
\hline $20: 1$ & - & - & 0.3 & 0.3 & $1 \cdot 0$ & - & $\mathbf{I} \cdot 6$ & 0.9 & $x \cdot 6$ & $I \cdot 6$ \\
\hline Total saturated & $4^{8}$ & $5 I$ & 49 & 49 & 47 & 38 & 37 & $3^{8}$ & 38 & 39 \\
\hline Total monoene & 32 & 31 & 25 & 25 & 22 & 35 & 38 & 32 & $3 r$ & 26 \\
\hline Total diene & 12 & Io & 6 & 6 & 6 & I8 & 16 & $x_{4}$ & 13 & I I \\
\hline Total polyene & 8 & 8 & 20 & 20 & 24 & 9 & 9 & 17 & I 7 & 24 \\
\hline
\end{tabular}

Inclusion of beef fat in the diet slightly raised the stearic to palmitic and oleic to palmitoleic ratios in the free fatty acids, but failed to depress the linoleate content. Fish oil, on the other hand, caused a partial replacement of linoleic and arachidonic acids, as well as of oleic acid, by fish-oil polyunsaturates, and the concentration of these acids reached rather higher values in the free fatty acids than in the triglyceride fraction.

Diglycerides. Slight but definite differences were again apparent between the compositions of the diglyceride fraction from breast and leg muscle, particularly in the proportions of saturated and unsaturated fatty acids present (Table 4 ). The presence 
of palmitaldehyde (16:A) and of higher proportions of the $20: 4$ and $22: 6$ acids in the diglyceride fraction suggests a relationship with phospholipids as well as with triglycerides, presumably of 1,2-diglycerides with phospholipids and of 1,3-diglycerides with triglycerides.

Fish oil in the diet caused the appearance of the fish-oil polyunsaturated fatty acids in the diglyceride fraction, mainly at the expense of linoleic, oleic and arachidonic acids. Dietary beef fat had a much smaller depressing effect on linoleic acid deposition and raised the oleic to palmitoleic ratio only slightly: the stearic to palmitic ratio was not affected.

Table 5. Fatty-acid compositions (wt \%) of the cholesterol ester fractions of the muscle lipids of turkeys receiving diets $E$ (control) and $A-D^{*}$

\begin{tabular}{|c|c|c|c|c|c|c|c|c|c|c|}
\hline \multirow[b]{2}{*}{ Fatty acid } & \multicolumn{5}{|c|}{ Breast muscle } & \multicolumn{5}{|c|}{ Leg muscle } \\
\hline & $\mathrm{E}$ & A & B & $\mathrm{C}$ & D & $\mathrm{E}$ & A & B & $\mathrm{C}$ & $\mathrm{D}$ \\
\hline \multicolumn{11}{|c|}{ Major constituents (> $2 \%$ ) } \\
\hline $12: 0$ & $\mathrm{I} \cdot 5$ & $2 \cdot 0$ & $2 \cdot 4$ & $2 \cdot I$ & $2 \cdot 4$ & $1 \cdot 5$ & $2 \cdot x$ & $2 \cdot 0$ & $2 \cdot \mathbf{I}$ & $2 \cdot 2$ \\
\hline 14:0 & $2 \cdot 4$ & $3 \cdot 7$ & $4 \cdot 3$ & 4.8 & $5 \cdot \mathrm{I}$ & $3 \cdot 3$ & 3.5 & $4 \cdot 9$ & $5 \cdot 0$ & $5 \cdot 7$ \\
\hline I $5: 0$ & $I \cdot 3$ & $I \cdot 7$ & $2 \cdot 4$ & $2 \cdot 4$ & $2 \cdot 0$ & $I \cdot I$ & 1.8 & $\mathbf{x} 8$ & $2 \cdot 0$ & $1 \cdot 7$ \\
\hline $16: 0$ & $24 \cdot 8$ & $23^{\circ} \circ$ & $23 \cdot 2$ & 23.4 & $2 \mathrm{I} \cdot 4$ & 30.3 & $27 \cdot 9$ & $24 \cdot 7$ & $25 \cdot 3$ & 24.5 \\
\hline I6:I & $\mathrm{II} \cdot 8$ & 10.7 & $7 \cdot 1$ & 6.8 & 47 & $12 \cdot 8$ & 10.7 & 10.7 & 10.2 & 9.9 \\
\hline $17: 0$ & $2 \cdot 0$ & $2 \cdot 0$ & 4.0 & $3 \cdot 4$ & $3 \cdot 1$ & 0.5 & $3 \cdot 2$ & $x \cdot 6$ & $3 \cdot 4$ & $2 \cdot 4$ \\
\hline $18: 0$ & $4 \cdot 8$ & $7 \cdot 0$ & $6 \cdot 4$ & $6 \cdot 8$ & $6 \cdot 3$ & 6.0 & $7 \cdot 8$ & $6 \cdot 7$ & 6.8 & $6 \cdot 4$ \\
\hline I $8: \mathrm{I}$ & $2 I \cdot 0$ & $22 \cdot 4$ & 17.7 & $17 \cdot 7$ & 15.8 & $18 \cdot 3$ & $17 \cdot 8$ & I4. I & $r_{3} \cdot I$ & $12 \cdot I$ \\
\hline$x 8: 2$ & $17 \cdot 8$ & 12.7 & $\mathrm{rI} \cdot 6$ & $12 \cdot 1$ & 9.9 & 13.9 & II. 2 & 10.3 & 10.1 & $8 \cdot 0$ \\
\hline I8:3 & $2 \cdot 3$ & $3 \cdot 2$ & $3 \cdot 6$ & $3 \cdot 7$ & $4 \cdot 6$ & $1 \cdot 3$ & $2 \cdot 5$ & $3 \cdot 3$ & $3 \cdot 4$ & $3 \cdot 8$ \\
\hline $20: 3 \omega 6$ & $8 \cdot 2$ & $7 \cdot 4$ & $5 \cdot 2$ & 5.3 & $5 \cdot 9$ & 8.9 & $8 \cdot 4$ & $7 \cdot 1$ & 6.9 & 5.8 \\
\hline $20: 5$ & - & $I \cdot 2$ & $5 \cdot I$ & $4 \cdot 9$ & $7 \cdot 6$ & $\mathrm{Tr}$ & $1 \cdot 2$ & 5.9 & $5 \cdot 7$ & $7 \cdot 7$ \\
\hline $22: 4$ & 0.5 & 0.5 & $x \cdot 9$ & $2 \cdot 4$ & 2.5 & 0.3 & 0.5 & 1.6 & $x \cdot 2$ & $2 \cdot I$ \\
\hline $22: 5^{\omega} 3$ & - & 0.6 & $I \cdot 2$ & $\mathrm{I} \cdot 3$ & $2 \cdot 4$ & - & $\mathrm{Tr}$ & I. 4 & $I \cdot 5$ & $1 \cdot 4$ \\
\hline $22: 6$ & - & 0.6 & $3 \cdot I$ & $2 \cdot 4$ & 43 & - & $\mathrm{Tr}_{\mathrm{r}}$ & $2 \cdot 9$ & $2 \cdot 7$ & $4 \cdot \pi$ \\
\hline \multicolumn{11}{|c|}{ Minor constituents $(<2 \%)$} \\
\hline $16: 2$ & - & - & - & - & 0.6 & - & - & - & - & 0.6 \\
\hline $\begin{array}{l}18: 4 \\
\end{array}$ & - & - & - & - & 0.6 & - & - & - & - & 0.6 \\
\hline $20: 4$ & $I \cdot 6$ & $I \cdot 2$ & 0.8 & 0.7 & 0.9 & 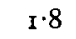 & $I \cdot 4$ & 0.9 & 0.7 & $I \cdot I$ \\
\hline Total saturated & 37 & 39 & 43 & 43 & 40 & 43 & 46 & 42 & 45 & 43 \\
\hline Total monoene & 33 & 33 & 25 & 24 & 21 & 31 & 29 & 25 & 23 & 22 \\
\hline Total diene & 18 & I3 & 12 & 12 & 10 & $I_{4}$ & II & Io & 10 & 8 \\
\hline Total polyene & 13 & I5 & $2 I$ & 21 & 29 & 12 & 14 & 23 & 22 & 27 \\
\hline
\end{tabular}

Cholesterol esters and unidentified lipid $(X)$. Both of these fractions, particularly lipid $X$, were present only in very minor proportions in the muscle lipids and their determination by GLC, carried out at higher sensitivity, might be less accurate than those of the larger fractions. Nevertheless, the measure of general agreement observed between the independent analyses of the corresponding breast and leg muscle fractions (Tables 5 and 6) suggests that no major loss of reproducibility had occurred.

In the GLC analyses of the cholesterol ester fractions two peaks, representing $12-16 \%$ of the total and running in the $\mathrm{C}_{22}$ unsaturated ester region, could not be 
identified with any known fatty-acid methyl ester. These peaks, which may have been artifacts produced by degradation of cholesterol during the transesterification process (cf. Shapiro \& Kritchevsky, I965), have not been included in the results.

Inclusion of beef fat in the diet slightly reduced the proportion of linoleic acid present in the cholesterol ester and lipid $X$ fractions without appreciably affecting oleic acid, whereas inclusion of fish oil depressed both to make way for some deposition of polyunsaturated fish-oil acids in both lipids. There were slight reductions in palmitoleic and palmitic acids also, in the cholesterol ester fraction.

Table 6. Fatty-acid compositions (wt \%) of the 'lipid X' fraction of the muscle lipids of turkeys receiving diets $E$ (control) and $A-D^{*}$

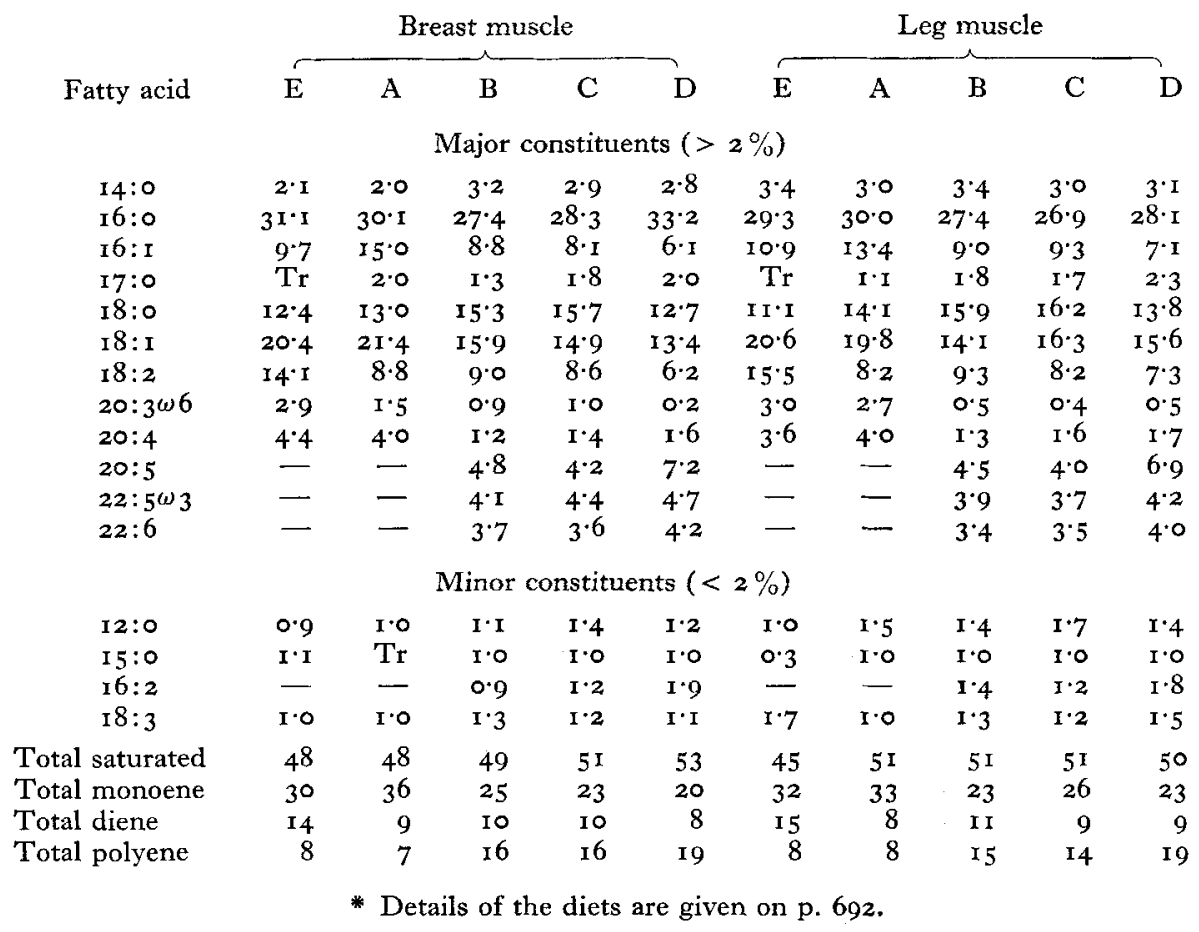

\section{Composition of the muscle phospholipids}

Phosphatidylcholine. The fatty-acid composition of PC, the most abundant of the individual phospholipids of muscle, differed only slightly in breast and leg (Table 7), but some of the minor differences observed, e.g. in the 16:0, 18:0, 20:5 and 22:6 acids, were consistent throughout the series. Palmitic acid ( $16: 0$ ), at $24-28 \%$, was a major constituent of $\mathrm{PC}$, with stearic acid present at about half these levels (I I-I $4 \%$ ). Palmitaldehyde (I6:A) occurred at a concentration of 4-5\% and stearaldehyde ( $18: \mathrm{A})$ as a minor constituent $(\mathrm{I}-2 \%)$ in all samples.

The inclusion of fish oil in the diet led to a fairly extensive deposition of the characteristic polyunsaturated fish oil acids in PC, apparently at the expense mainly of linoleic (18:2) and, in less degree oleic (I8:1) acids. The small proportion of arachi- 
donic (20:4) acid present showed only small and erratic variations. Dietary beef fat had very little effect on the composition of the PC fraction.

Phosphatidylethanolamine. The PE fractions from breast and leg muscle also showed a number of small but consistent differences, though the overall pattern remained closely similar (Table 8). Palmitaldehyde (r6:A) was now present as one of the largest constituents ( $12-15 \%)$ and stearaldehyde (18:A) was also higher at $6-7 \%$. These figures indicate a plasmalogen content of as much as $40 \%$ in the PE fraction, a very

Table 7. Fatty-acid compositions (wt \%) of the phosphatidylcholine fraction of the muscle lipids of turkeys receiving diets $E$ (control) and $A-D^{*}$

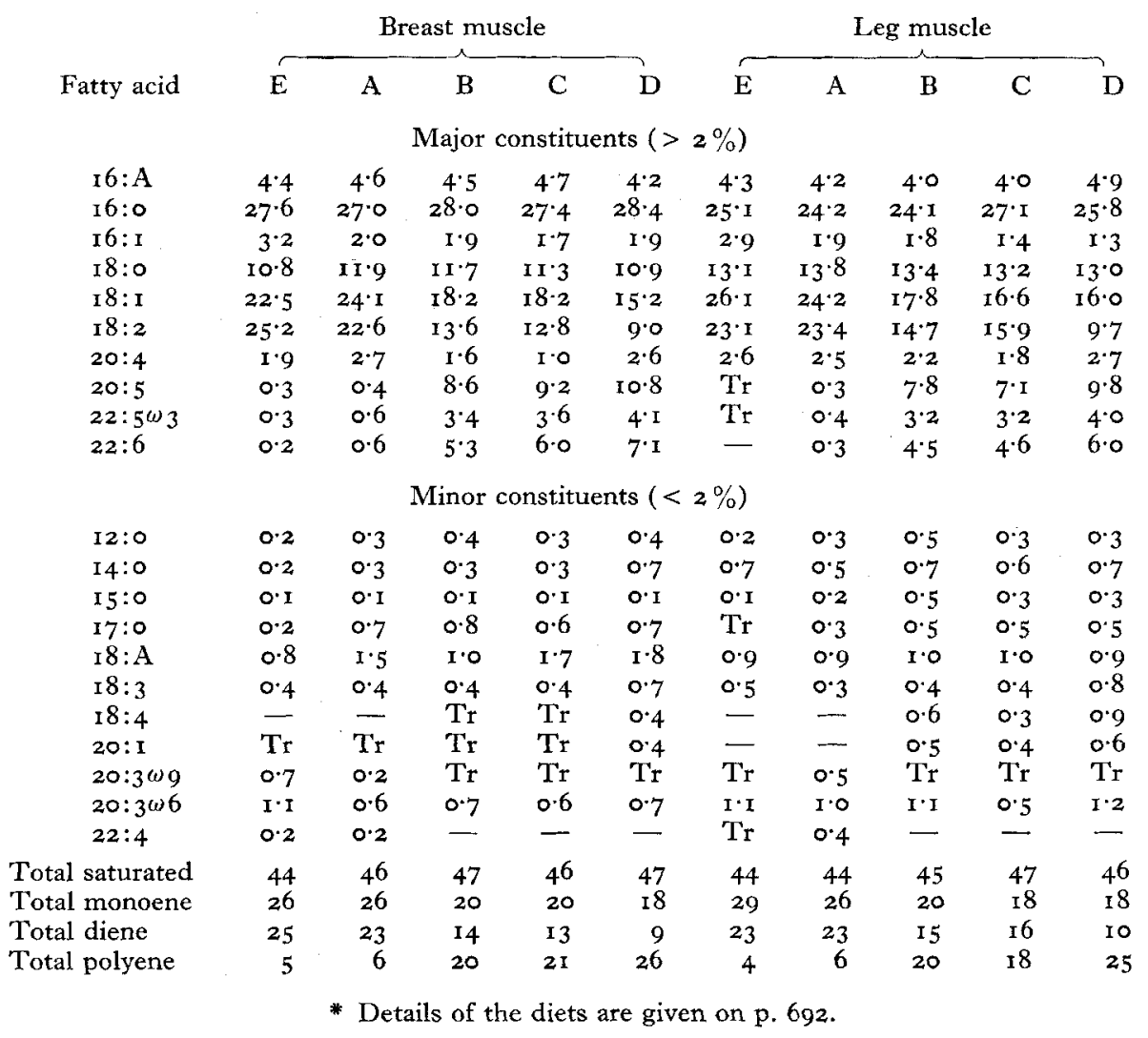

much higher proportion than the $3 \cdot 5-5.2 \%$ found in chicken muscle PE by Peng $\&$ Dugan ( $1_{96}$ ). The discrepancy may be accounted for by the observation of Sgoutas (1966) that plasmalogens suffer extensive degradation during chromatography on silicic acid columns, with loss of their aldehydes.

Incorporation of the fish-oil acids, particularly those of highest unsaturation (22:6 and 20:5), reached very high levels in PE, linoleic (I8:2) and oleic (I8: I) again being the major acids replaced, but now with a major displacement of arachidonic $(20: 4)$ acid also.

Despite the high levels of stearic, palmitic and oleic acids in the diet supplemented 
with beef fat (A) there was, as with $\mathrm{PC}$, no appreciable increase in the deposition of these more saturated fatty acids in the highly unsaturated PE fraction.

Phosphatidylserine. Like PC and PE, PS contained a high proportion of polyunsaturated fatty acids, but stearic acid, at $32-34 \%$, was much higher in PS than in either of the other two lipids. Another difference was that aldehydes were absent (Table 9).

Table 8. Fatty-acid compositions (wt \%) of the phosphatidylethanolamine fraction of the muscle lipids of turkeys receiving diets $E$ (control) and $A-D^{*}$

\begin{tabular}{|c|c|c|c|c|c|c|c|c|c|c|}
\hline \multirow[b]{2}{*}{ Fatty acid } & \multicolumn{5}{|c|}{ Breast muscle } & \multicolumn{5}{|c|}{ Leg muscle } \\
\hline & $\mathrm{E}$ & A & B & $\mathrm{C}$ & $\mathrm{D}$ & $E$ & A & $\mathbf{B}$ & $\mathrm{C}$ & $\mathrm{D}$ \\
\hline \multicolumn{11}{|c|}{ Major constituents ( $>2 \%$ ) } \\
\hline 16:A & $\mathrm{I} 4 \cdot 2$ & $14 \cdot 4$ & $14 \cdot 4$ & 14.3 & $14 \cdot 6$ & I $2 \cdot I$ & $12 \cdot 0$ & I2:I & $12 \cdot 0$ & I I 8 \\
\hline $16: 0$ & 4.5 & $4 \cdot 8$ & $4 \cdot 8$ & $5 \cdot 0$ & $4 \cdot 7$ & $6 \cdot 1$ & $6 \cdot 0$ & $6 \cdot 2$ & $6 \cdot 3$ & $6 \cdot 0$ \\
\hline I8:A & $7 \cdot 1$ & $7 \cdot 1$ & $7 \cdot 4$ & $7 \cdot 3$ & $6 \cdot 9$ & $6 \cdot 0$ & $6 \cdot 1$ & $5 \cdot 9$ & 6.0 & $5 \cdot 8$ \\
\hline $18: 0$ & I $5 \cdot 4$ & $15 \cdot 2$ & $15 \cdot 9$ & $16 \cdot 3$ & I5.5 & $17 \cdot 7$ & $19 \cdot 0$ & I $8 \cdot 9$ & I9. I & I $8 \cdot 8$ \\
\hline I8: I & $13 \cdot 6$ & 13.8 & $9 \cdot 3$ & $9 \cdot 4$ & $5^{\cdot 6}$ & 10.6 & $\mathrm{II} \cdot 4$ & $6 \cdot 9$ & $7 \cdot 4$ & 4.5 \\
\hline r $8: 2$ & $16 \cdot 2$ & $14 \cdot 2$ & $7 \cdot 9$ & $7 \cdot 7$ & $3 \cdot 6$ & $x 6.8$ & I I'9 & $6 \cdot 1$ & $6 \cdot 7$ & $3 \cdot 6$ \\
\hline $20: 4$ & 13.0 & 12.0 & $4 \cdot 2$ & $4 \cdot I$ & 3.5 & $I 6 \cdot I$ & $17^{\prime} 2$ & $5 \cdot 4$ & $5 \cdot 6$ & $4 \cdot 8$ \\
\hline $20: 5$ & $1 \cdot 4$ & I-8 & $8 \cdot 9$ & $8 \cdot 8$ & I $1 \cdot 5$ & $\mathbf{I} \cdot 3$ & $2 \cdot 3$ & 10.0 & $9 \cdot 8$ & $12 \cdot 7$ \\
\hline $22: 4$ & $3 \cdot 7$ & $2 \cdot 8$ & $1 \cdot 0$ & 0.9 & $I \cdot I$ & $2 \cdot 8$ & $2 \cdot 5$ & - & $O \cdot I$ & 0.3 \\
\hline $22: 5 \omega 3$ & $2 \cdot 7$ & $3 \cdot 6$ & $4 \cdot 2$ & $4 \cdot 1$ & 4.4 & $2 \cdot 8$ & 3.2 & 3.6 & 3.5 & $3 \cdot 8$ \\
\hline $22: 6$ & $2 \cdot 0$ & $3 \cdot 3$ & 19.2 & I $9^{\circ} \mathrm{I}$ & $23 \cdot 6$ & $2 \cdot 0$ & $2 \cdot 8$ & $17 \cdot 8$ & $17 \cdot 4$ & $2 \mathrm{I} \cdot 8$ \\
\hline \multicolumn{11}{|c|}{ Minor constituents $(<2 \%)$} \\
\hline $14: 0$ & 0.4 & 0.3 & 0.4 & 0.4 & 0.4 & 0.4 & 0.4 & 0.5 & 0.5 & 0.5 \\
\hline $15: 0$ & 0.1 & 0.1 & 0.1 & $0 \cdot 1$ & 0.1 & 0.3 & 0.3 & 0.3 & 0.3 & 0.3 \\
\hline I6:I & I. 5 & $r \cdot 6$ & I.O & $I \cdot I$ & 0.4 & $I \cdot 4$ & 1.0 & $I \cdot 2$ & $\mathrm{x} \cdot 5$ & $I \cdot 2$ \\
\hline I6:2 & - & $\operatorname{Tr}$ & 0.2 & 0.2 & $0 \cdot 3$ & - & - & 0.6 & 0.7 & 0.8 \\
\hline $17: 0$ & 0.4 & $O \cdot I$ & 0.1 & 0.2 & 0.3 & 0.4 & 0.6 & 0.6 & 0.6 & 0.4 \\
\hline I $8: 3$ & 0.4 & 0.4 & 0.3 & 0.4 & 0.7 & 0.5 & $I \cdot 7$ & I. 8 & $\mathrm{I} \cdot 6$ & $\mathrm{I} \cdot 3$ \\
\hline $18: 4$ & $\operatorname{Tr}$ & - & 0.3 & 0.3 & 0.9 & - & $-\dot{-}$ & $\mathrm{Tr}$ & $\mathrm{Tr}$ & $\mathrm{Tr}$ \\
\hline $20: 0$ & $T_{\mathbf{r}}$ & - & $0 \cdot 1$ & 0.1 & 0.1 & - & - & - & - & - \\
\hline $20: 1$ & $\operatorname{Tr}$ & - & 0.2 & 0.2 & 0.6 & 0.2 & $\operatorname{Tr}$ & $\operatorname{Tr}$ & $\operatorname{Tr}$ & $\operatorname{Tr}$ \\
\hline $20: 3^{\omega 9}$ & $1 \cdot 5$ & $1 \cdot 3$ & 一 & - & - & $1 \cdot 9$ & $\mathbf{r} \cdot \mathbf{O}$ & - & 一 & 一 \\
\hline $20: 3^{\omega 6}$ & $I \cdot I$ & $I \cdot 2$ & 0.6 & 0.5 & 0.7 & 0.8 & 0.9 & 0.3 & 0.3 & 0.5 \\
\hline $22: 3$ & 0.6 & 0.7 & 0.2 & 0.2 & 0.3 & $\mathrm{Tr}$ & 0.1 & $1 \cdot 0$ & 0.5 & 0.8 \\
\hline $22: 5 \omega 6$ & 0.6 & 0.5 & 一 & - & - & $\operatorname{Tr}$ & 0.1 & - & 0.1 & 0.3 \\
\hline Total saturated & 42 & 42 & 43 & 44 & 43 & 43 & 44 & 45 & 45 & 44 \\
\hline Total monoene & I 5 & I5 & IO & II & 7 & 12 & I2 & 8 & 9 & 6 \\
\hline Total diene & I6 & I4 & 8 & 8 & 4 & I7 & 12 & 7 & 7 & 4 \\
\hline Total polyene & 27 & 28 & 39 & $3^{8}$ & 47 & 28 & 32 & 40 & 39 & 46 \\
\hline
\end{tabular}

The polyunsaturated acids of dietary fish oil, particularly 22:6, were extensively incorporated into PS, again at the expense particularly of linoleic (18:2) and, in less degree, oleic (18:I), but, as with PC, the comparatively small amount of arachidonic $(20: 4)$ acid present in PS was not greatly affected. Beef fat in the diet had very little effect on the fatty-acid composition of the PS fraction of the muscle lipid.

Phosphatidylinositol. The PI fraction derived from breast and leg muscle again showed a number of small and on the whole consistent differences in composition (e.g. in $16: 0,18: 0,18: 4$ ) without, however, any major difference in overall pattern 
(Table ro). In PI stearic acid reached the unusually high level of $39-44 \%$, which is in agreement with the $38.5 \%$ of this acid found by Sgoutas (1966) in PI from chicken liver. Palmitic acid, at 4-5\% was, however, much lower than the $25.9 \%$ reported by Sgoutas, though in agreement with the low values found in PI from pigeon pancreas by Keenan \& Hokin (1964) and in PI from calf brain by Kerr \& Read (1963).

Deposition of the polyunsaturated fatty acids of the fish oil was again extensive,

Table 9. Fatty-acid compositions (wo \%) of the phosphatidylserine fraction of the muscle lipids of turkeys receiving diets $E$ (control) and $A-D^{*}$

\begin{tabular}{|c|c|c|c|c|c|c|c|c|c|c|}
\hline \multirow[b]{2}{*}{ Fatty acid } & \multicolumn{5}{|c|}{ Breast muscle } & \multicolumn{5}{|c|}{ Leg muscle } \\
\hline & $\mathrm{E}$ & A & $\mathrm{B}$ & $\mathrm{C}$ & $\mathrm{D}$ & $\mathrm{E}$ & A & B & $\mathrm{C}$ & D \\
\hline \multicolumn{11}{|c|}{ Major constituents $(>2 \%)$} \\
\hline I6:0 & $10 \cdot 7$ & 10.2 & $10 \% 4$ & $10 \cdot 3$ & $9 \cdot 9$ & 10.0 & $11 \cdot 4$ & II 6 & $\mathrm{II} \cdot 3$ & 10.8 \\
\hline I6: I & $2 \cdot 5$ & 0.7 & $I \cdot 2$ & $\mathrm{r} \cdot 2$ & 0.9 & $2 \cdot I$ & $I \cdot I$ & $I \cdot 2$ & $I \cdot 4$ & $1 \cdot 0$ \\
\hline I 8:0 & $33 \cdot 5$ & $32 \cdot 2$ & $3 I \cdot 9$ & $33 \cdot 2$ & $32 \cdot 3$ & $32 \cdot 0$ & $32 \cdot 0$ & $43 \cdot 2$ & $34^{\prime} \mathrm{I}$ & $33 \cdot 0$ \\
\hline I $8: 1$ & $19 \cdot 7$ & 19.6 & I 5.8 & I 5.5 & $12 \cdot 7$ & $20 \cdot I$ & 19.3 & 15.7 & $15 \times 9$ & 14.3 \\
\hline I $8: 2$ & $2 \mathrm{I} \cdot 8$ & $19^{\circ} 1$ & $9 \cdot 8$ & 10.6 & $5 \cdot I$ & $24 \cdot 4$ & $20 \cdot 2$ & $8: 4$ & $8 \cdot z$ & $5 \cdot 3$ \\
\hline $20: 3 \omega 6$ & $3 \cdot 4$ & $4 \cdot I$ & $2 \cdot 7$ & $2 \cdot 9$ & $3 \cdot 8$ & $2 \cdot 3$ & $2 \cdot I$ & $2 \cdot 8$ & $2 \cdot 9$ & $2 \cdot 7$ \\
\hline $20: 4$ & $4 \cdot 3$ & 377 & $2 \cdot 4$ & $2 \cdot 6$ & $3 \cdot 5$ & $4 \cdot 4$ & $4 \cdot 0$ & $3 \cdot 5$ & $3 \cdot 7$ & 4.0 \\
\hline $20: 5$ & 0.2 & $I \cdot 0$ & $2 \cdot 4$ & $2 \cdot 3$ & $3 \cdot 5$ & $\mathrm{Tr}$ & 0.4 & $3 \cdot 1$ & 3.0 & $4 \cdot 5$ \\
\hline $22: 5 \omega 6$ & $\mathrm{Tr}$ & $\operatorname{Tr}$ & $3 \cdot 2$ & $3 \cdot 2$ & $5 \cdot 8$ & $\mathbf{T r}$ & $\operatorname{Tr}$ & $2: 1$ & $2 \cdot 0$ & $2 \cdot 4$ \\
\hline $22: 5^{\omega} 3$ & 0.2 & $2 \cdot 4$ & $4^{\cdot I}$ & $4^{\circ} 0$ & $4 \cdot 3$ & $\mathbf{T r}$ & $2 \cdot 0$ & $3 \cdot 7$ & $3 \cdot 6$ & $4 \cdot 0$ \\
\hline $22: 6$ & 0.1 & $3 \cdot 0$ & $10 \cdot 9$ & $9^{\circ} 9$ & $12 \cdot 7$ & $\operatorname{Tr}$ & $\mathrm{I} \cdot 8$ & $9 \cdot 0$ & $8 \cdot 9$ & II 5 \\
\hline \multicolumn{11}{|c|}{ Minor constituents $(<2 \%)$} \\
\hline 12:0 & I.O & 0.4 & 0.8 & 0.7 & 0.9 & 0.5 & 0.5 & 0.5 & 0.5 & 0.5 \\
\hline $14: 0$ & 0.7 & 0.5 & 0.8 & 0.7 & 0.9 & $I \cdot 9$ & $1 \cdot 0$ & $\mathbf{r} \cdot 0$ & $\mathrm{r} \cdot \mathrm{O}$ & $x \cdot 5$ \\
\hline $15: 0$ & $\operatorname{Tr}$ & $\operatorname{Tr}$ & $\mathrm{Tr}$ & $\operatorname{Tr}$ & $\operatorname{Tr}$ & 0.4 & 0.4 & 0.5 & 0.5 & 0.5 \\
\hline I6:A & 0.5 & 0.5 & 0.5 & 0.4 & 0.5 & 0.2 & 0.2 & 0.2 & 0.2 & 0.2 \\
\hline $16: 2$ & - & - & 0.4 & 0.2 & 0.6 & - & - & 0.8 & 0.9 & $\mathbf{I} \cdot 3$ \\
\hline $17: 0$ & $I \cdot 2$ & 0.6 & $I \cdot \mathbf{I}$ & 0.8 & 0.9 & 0.4 & $I \cdot 0$ & 0.3 & 0.5 & 0.5 \\
\hline I $8: \mathrm{A}$ & 0.1 & $0 \cdot I$ & $0 \cdot 1$ & $0 \cdot 2$ & 0.1 & $\operatorname{Tr}$ & $\operatorname{Tr}$ & $\operatorname{Tr}$ & $\operatorname{Tr}$ & $\mathrm{Tr}$ \\
\hline $18: 3$ & 0.2 & 0.2 & 0.7 & 0.6 & $I \cdot 3$ & 0.4 & 0.7 & $I \cdot 4$ & $I \cdot 3$ & $I \cdot 4$ \\
\hline $18: 4$ & - & - & 0.2 & 0.2 & 0.7 & - & - & $\mathrm{Tr}$ & $\mathrm{Tr}$ & 0.3 \\
\hline $22: 4$ & $\operatorname{Tr}$ & $\mathbf{I} \cdot 6$ & $\operatorname{Tr}$ & $\operatorname{Tr}$ & $\operatorname{Tr}$ & 0.9 & $I \cdot 9$ & - & - & 一 \\
\hline Total saturated & 48 & 45 & 46 & 46 & 45 & 45 & 46 & 48 & 48 & 46 \\
\hline Total monoene & 22 & 20 & 17 & 17 & 14 & 22 & 20 & 17 & I 7 & 15 \\
\hline Total diene & 22 & 19 & ro & I I & 6 & 24 & 20 & 9 & 9 & 7 \\
\hline Total polyene & 8 & 16 & 27 & 26 & 36 & 8 & 13 & 26 & 25 & $3 I$ \\
\hline
\end{tabular}

apparently at the expense mainly of the $18: 2,18: \mathrm{I}$ and $20: 3^{\omega} \omega$ acids. Arachidonic $(20: 4)$ acid, in which the PI fraction was exceptionally rich ( $>20 \%)$ was not affected, except for a slight depression at the higher level of dietary fish oil (diet D). Even without any special dietary supplementation the tendency for this lipid to contain high proportions of saturated (mainly stearic) and polyene acids is remarkable, and when the diet with fish oil was given nearly every molecule contained one long-chain saturated and one long-chain highly unsaturated fatty acid (Table ro).

Sphingomyelin. The SP fraction differed completely in fatty-acid composition from all the other muscle lipids, containing mainly saturated (about 80\%) and monounsaturated acids (about $19 \%$ ) in wide variety (Table II). The most highly un- 
saturated acid present was linoleic ( $18: 2$ ), at a concentration of only $I-2 \%$, and this composition was unaffected even when fish oil (or beef fat) was given. Every acid (except $\mathrm{C}_{13}$ ) from $\mathrm{C}_{12}$ to $\mathrm{C}_{25}$ was present among the saturated acids, the even-numbered as major and the odd-numbered usually as minor components, but only palmitic $(21-25 \%)$ and stearic $(20-23 \%)$ exceeded 10\%. Aldehydes were absent.

This composition differs materially from that of chicken muscle SP analysed by Peng \& Dugan (I965), who found 9.3\% I0:0, 10.3\% II:0, 10.1 $\%$ I $8: 2$ and $4.2 \%$

'Table ı. Fatty-acid compositions (wt \%) of the phosphatidylinositol fraction of the muscle lipids of turkeys receiving diets $E$ (control) and $A-D^{*}$

\begin{tabular}{|c|c|c|c|c|c|c|c|c|c|c|}
\hline \multirow[b]{2}{*}{ Fatty acid } & \multicolumn{5}{|c|}{ Bteast muscle } & \multicolumn{5}{|c|}{ Leg muscle } \\
\hline & $\mathrm{E}$ & $A$ & B & C & $\mathrm{D}$ & $\mathbf{E}$ & A & $\mathrm{B}$ & $\mathbf{C}$ & $\mathrm{D}$ \\
\hline \multicolumn{11}{|c|}{ Major constituents $(>2 \%)$} \\
\hline I6:0 & $5 \cdot 0$ & $5 \cdot 2$ & $4 \cdot 6$ & $4 \cdot 5$ & $4 \cdot 0$ & $4 \cdot 1$ & 4.0 & $4 \cdot \pi$ & $3 \cdot 9$ & $3 \cdot 6$ \\
\hline I $8: 0$ & $40 \cdot 0$ & $40 \cdot 2$ & $4 I \cdot 2$ & $40 \cdot 9$ & $39 \cdot 3$ & $43^{-2}$ & $44 \cdot I$ & 43.7 & $43 \cdot 2$ & $4 I^{\circ} 9$ \\
\hline I $8:$ I & IO. I & 9.9 & $3 \cdot 5$ & $3 \cdot 6$ & $3 \cdot 7$ & 10.7 & $8 \cdot 0$ & $3 \cdot 8$ & $3 \cdot 8$ & $3 \cdot 4$ \\
\hline $18: 2$ & $7 \cdot 1$ & $8 \cdot 2$ & $2 \cdot 9$ & $3 \cdot 0$ & $2 \cdot 0$ & $8 \cdot 4$ & $8 \cdot 0$ & $2 \cdot 5$ & $2 \cdot 0$ & $1 \cdot 5$ \\
\hline $20: 3 \omega 9$ & 8.0 & $5 \cdot 7$ & 0.6 & 0.6 & 0.7 & 4. I & 4.0 & $1 \cdot 0$ & $I \cdot 2$ & $I \cdot 1$ \\
\hline $20: 3 \omega 6$ & $4 \cdot 3$ & $2 \cdot 0$ & $2 \cdot 6$ & $2 \cdot 6$ & $2 \cdot 9$ & 1.6 & $1 \cdot 6$ & $2 \cdot 2$ & $2 \cdot 0$ & $2 \cdot 0$ \\
\hline $20: 4$ & $21 \cdot 5$ & $2 I 0$ & 20.7 & 210 & I8.8 & $22 \cdot 8$ & $23 \cdot 6$ & $23 \cdot I$ & $24 \cdot 1$ & 19.9 \\
\hline $20: 5$ & $\mathrm{Tr}$ & I. 4 & $8 \cdot 3$ & $7 \cdot 9$ & $9 \cdot 9$ & $\operatorname{Tr}$ & 0.6 & 6.7 & $6 \cdot 6$ & $9 \cdot 4$ \\
\hline $22: 5 \omega 6$ & - & - & $1 \cdot 8$ & $\mathrm{I} \cdot 8$ & $2 \cdot 7$ & - & - & $\operatorname{Tr}$ & $\mathrm{Tr}$ & 0.7 \\
\hline $22: 5 \omega_{3}$ & $1 \cdot 4$ & $I \cdot 9$ & $5 \cdot 5$ & $5 \cdot 3$ & $5 \cdot 6$ & 0.5 & $I \cdot 7$ & $5 \cdot 0$ & $5 \circ$ & $4 \cdot 9$ \\
\hline $22: 6$ & $\operatorname{Tr}$ & $I \cdot 2$ & 3.9 & $4 \cdot 0$ & $6 \cdot 5$ & $\operatorname{Tr}$ & 0.5 & $4 \cdot 0$ & $4^{-1}$ & $6 \cdot 6$ \\
\hline \multicolumn{11}{|c|}{ Minor constituents $(<2 \%)$} \\
\hline $12: 0$ & 0.3 & 0.4 & 0.5 & 0.5 & 0.4 & 0.6 & 0.5 & 0.5 & 0.5 & 0.5 \\
\hline $14: 0$ & 0.3 & 0.5 & 0.5 & 0.5 & 0.4 & $\mathbf{I} \cdot 0$ & $I \cdot 0$ & $I \cdot O$ & $I \cdot 0$ & $r \cdot 0$ \\
\hline $15: 0$ & $T_{r}$ & $\operatorname{Tr}$ & $\operatorname{Tr}$ & $\operatorname{Tr}$ & $\mathrm{Tr}$ & 0.6 & 0.5 & 0.5 & 0.5 & 0.5 \\
\hline I6: $x$ & $x \cdot 2$ & $\mathrm{I} \cdot \mathrm{O}$ & $I \cdot 0$ & $I \cdot I$ & 0.7 & $\mathbf{I} \cdot 9$ & 0.9 & I.O & $I \cdot 0$ & $I \cdot O$ \\
\hline $17: 0$ & $I \cdot O$ & $1 \cdot 0$ & $1 \cdot 0$ & $I \cdot O$ & 0.7 & 0.4 & $I \cdot I$ & $\mathbf{I} \cdot 3$ & $I \cdot I$ & $1 \cdot 0$ \\
\hline $18: 3$ & $\operatorname{Tr}$ & $\operatorname{Tr}$ & 0.6 & 0.6 & 0.7 & $\operatorname{Tr}$ & $\mathrm{Tr}$ & 0.3 & 0.3 & 0.6 \\
\hline $22: 3$ & - & - & 0.6 & 0.7 & 0.4 & 一 & - & 0.4 & 0.4 & 0.2 \\
\hline $22: 4$ & - & - & 0.7 & 0.6 & 0.3 & - & 一 & 0.4 & 0.4 & 0.3 \\
\hline Total saturated & 47 & 47 & 48 & 47 & 45 & 50 & $5 I$ & $5 \mathrm{I}$ & 50 & 49 \\
\hline Total monoene & II & II & 5 & 5 & 4 & 13 & 9 & 5 & 5 & 4 \\
\hline Total diene & 7 & 8 & 3 & 3 & 2 & 8 & 8 & 2 & 2 & 2 \\
\hline Total polyene & 35 & 33 & 45 & 45 & 49 & 29 & 32 & 42 & 43 & 45 \\
\hline
\end{tabular}

20:4. It is in general agreement with the results of analysis of chicken liver SP by Sgoutas (1966), except for Sgoutas's surprising finding of $10.6 \%$ arachidonic $(20: 4)$ acid. Peng \& Dugan found no behenic (22:0) and Sgoutas no erucic (22:1), both of which as methyl esters are liable to run close to arachidonate, and in a complex mixture such as this errors in identification are possible.

Lysophosphatidylcholine. LPC was present only as a very minor proportion of the total phospholipids. Much less highly unsaturated than PC (74-79\% saturated acids as compared with $44-47 \%$ ), it nevertheless still contained 10-16\% monoene and $3-7 \%$ diene acids (Table 12 ). Polyunsaturated fatty acids derived from the fish-oil supplement in diets B, C and D were detectable in the LPC fraction, but only in very small amounts. 
Hydrolysis by phospholipase A. Thin-layer chromatography of the reaction product after hydrolysis showed that the venom enzyme completely removed one of the two fatty-acid radicals from $\mathrm{PC}$ in $2.5 \mathrm{~h}$ (similar to the $2 \mathrm{~h}$ used by Menzel \& Olcott at a probably higher room temperature), but that the reaction with $\mathrm{PE}$ was still not quite complete after $4 \mathrm{~h}$. However, the compositions of the reaction products separated after this time should still indicate the distribution of fatty acids between the one and two positions in the molecule, and the apparent specificity of the hydrolysis was, in

Table I I. Fatty-acid composition (wt \%) of the sphingomyelin fraction of the muscle lipids of turkeys receiving diets $E$ (control) and $A-D^{*}$

\begin{tabular}{|c|c|c|c|c|c|c|c|c|c|c|}
\hline \multirow[b]{2}{*}{ Fatty acid } & \multicolumn{5}{|c|}{ Breast muscle } & \multicolumn{5}{|c|}{ Leg muscle } \\
\hline & $\mathrm{E}$ & $\mathrm{A}$ & B & C & $\mathrm{D}$ & $\mathbf{E}$ & A & B & C & \\
\hline \multicolumn{11}{|c|}{ Major constituents $(>2 \%)$} \\
\hline I 2:0 & $\mathbf{I} \cdot \mathbf{2}$ & $\mathbf{r} \cdot \mathbf{2}$ & $I \cdot 3$ & $I \cdot 2$ & $1 \cdot 0$ & $2 \cdot 3$ & $2 \cdot 4$ & $2 \cdot 5$ & 2.5 & \\
\hline $14: 0$ & $2 \cdot 2$ & $2 \cdot 3$ & $3 \cdot 0$ & $3 \cdot I$ & $2 \cdot 9$ & $2 \cdot 4$ & $3 \cdot 4$ & $3 \cdot 9$ & $3 \cdot 9$ & $4^{*}$ \\
\hline $16: 0$ & $24 \cdot 9$ & $24 \cdot 1$ & $24 \cdot 0$ & $23 \cdot 8$ & $24^{\prime} I$ & $23 \cdot I$ & $2 I \cdot 5$ & $2 \mathrm{I} \cdot 4$ & $21 \cdot 8$ & 20.5 \\
\hline I6: I & $2 \cdot 2$ & $\mathrm{I} \cdot 7$ & $2 \cdot 2$ & $2 \cdot 0$ & $\mathbf{I} \cdot 7$ & $2 \cdot 3$ & $\mathrm{I} \cdot 4$ & $\mathbf{I} \cdot 8$ & I·9 & $2 \cdot 1$ \\
\hline $18: 0$ & $21 \cdot 8$ & $21 \cdot 7$ & $22 \cdot 6$ & $22 \cdot 6$ & $22 \cdot 2$ & $19 \cdot 8$ & $20 \cdot 2$ & 20.4 & $20 \cdot 6$ & 20.5 \\
\hline $18: 1$ & $5^{\cdot I}$ & $5 \cdot 1$ & $3 \cdot I$ & 3.0 & 2.5 & $5 \cdot 8$ & $5 \cdot 7$ & 3.0 & $3 \cdot 2$ & 27 \\
\hline $20: 0$ & 5.9 & $6 \cdot 3$ & $6 \cdot 6$ & $6 \cdot 5$ & 6.8 & $6 \cdot 2$ & $6 \cdot 0$ & 6.9 & $6 \cdot 2$ & 7 \\
\hline $22: 0$ & 6.9 & $7 \cdot 4$ & $7 \cdot 3$ & $7 \cdot 3$ & $7 \cdot 8$ & $6 \cdot 8$ & 7.0 & $7 \cdot 9$ & $7 \cdot 7$ & 8.0 \\
\hline $22: I$ & 2.9 & $2 \cdot I$ & $2 \cdot 0$ & $2 \cdot 0$ & $I \cdot 9$ & I $\cdot 8$ & $2 \cdot 3$ & 2.4 & $2 \cdot 6$ & $2 \cdot 4$ \\
\hline $24: 0$ & $7 \cdot 4$ & $8 \cdot 5$ & $8 \cdot 3$ & $8 \cdot 9$ & $8 \cdot 8$ & $8 \cdot 6$ & $9 \cdot 2$ & 9.0 & $9 \cdot 2$ & 9.0 \\
\hline $24: I$ & $8 \cdot 3$ & $8 \cdot 1$ & $8 \cdot 5$ & $8 \cdot 6$ & $8 \cdot 4$ & $8 \cdot 9$ & $8 \cdot 8$ & 9.1 & $8 \cdot 2$ & 9.0 \\
\hline $25:$ of & $2 \cdot 7$ & $\mathrm{I} \cdot 4$ & $r \cdot 5$ & $I ' 4$ & $I \cdot 6$ & $2 \cdot 3$ & $2 \cdot 2$ & $2 \cdot 2$ & $2 \cdot 4$ & 2 \\
\hline \multicolumn{11}{|c|}{ Minor constituents $(<2 \%)$} \\
\hline I5:0 & $I \cdot I$ & $I \cdot 2$ & $I \cdot I$ & $1 \cdot 3$ & $I \cdot I$ & $I \cdot O$ & 0.9 & 1.0 & $I \cdot O$ & $I \cdot O$ \\
\hline $17: 0$ & $I \cdot 4$ & $I \cdot 4$ & $1 \cdot 4$ & $I \cdot 3$ & $1 \cdot 2$ & $x \cdot 7$ & $2 \cdot 0$ & $I \cdot 9$ & $1 \cdot 7$ & I. 8 \\
\hline I $8: 2$ & $1 \cdot 8$ & $2 \cdot 0$ & 1.0 & $1 \cdot 0$ & I. 5 & $1 \cdot 7$ & $1 \cdot 7$ & 0.9 & $I \cdot I$ & 0.7 \\
\hline 19:0 & 0.5 & 0.8 & 1.0 & $I \cdot O$ & $I \cdot O$ & $I \cdot I$ & $1 \cdot 0$ & $I \cdot 0$ & $1 \cdot 0$ & $I . O$ \\
\hline $20: 1$ & 0.5 & 0.8 & $I \cdot 0$ & $1 \cdot 0$ & $I \cdot O$ & $I \cdot O$ & $1 \cdot 0$ & 1.0 & I'O & $I \cdot 0$ \\
\hline $21: 0$ & 0.5 & $I \cdot O$ & $I \cdot O$ & $I \cdot O$ & $I \cdot O$ & $I \cdot O$ & $1 \cdot 0$ & 1.0 & $I \cdot O$ & $1 \cdot 0$ \\
\hline $23: 0$ & $2 \cdot 0$ & $\mathrm{I} \cdot 8$ & $1 \cdot 6$ & 177 & $1 \cdot 8$ & $I \cdot 3$ & $1 \cdot 7$ & I. 4 & $I \cdot 3$ & $I \cdot 4$ \\
\hline $23: 1$ & 0.5 & 0.8 & 1.0 & 0.9 & I.O & $I \cdot O$ & $1 \cdot 0$ & $I \cdot O$ & $I \cdot O$ & $I \cdot O$ \\
\hline saturated & 79 & 79 & $8 I$ & $8 \mathrm{I}$ & $8 r$ & 78 & 79 & $8 I$ & 80 & 80 \\
\hline monoene & I 9 & I9 & I 8 & I 8 & 17 & $2 I$ & 20 & I 8 & I 8 & 18 \\
\hline diene & 2 & 2 & $\mathbf{r}$ & I & 2 & 2 & 2 & I & $\mathbf{I}$ & 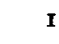 \\
\hline polyene & - & - & - & - & - & - & - & - & - & - \\
\hline
\end{tabular}

* Details of the diets are given on p. 692 .

+ The chromatograms were stopped at this point: small amounts of later running esters may have been present.

fact, higher with PE than with PC. In view of the limited overall accuracy of the several stage procedure necessary for these analyses the figures in Table ${ }_{3} 3$ have been rounded to the nearest unit $\%$.

\section{DISCUSSION}

Diets $A$ and $A$ r. Throughout the work analyses of lipid fractions from the two groups, A and A I, receiving the diet supplemented with beef fat, showed only random variations attributable to experimental error, and values reported as for $\operatorname{diet} \mathrm{A}$ in a majority of the tables are means derived from analyses of both samples. 
Effect of EMQ in the diet. Diets B and C (basal supplemented with $2.5 \%$ anchovy oil) differed only in the incorporation in diet $\mathrm{C}$ of $0.02 \%$ of the antioxidant EMQ. This substance is known to afford protection against some of the physiologically harmful effects of dietary polyunsaturated fat and, in the present experiments it markedly increased both the stability of the skin fat towards autoxidation and the storage of vitamins A and E (Neudoerffer \& Lea, 1966a).

Table I2. Fatty-acid compositions (wt \%) of the lysophosphatidylcholine fraction of the muscle lipids of turkeys receiving diets $E$ (control) and $A-D^{*}$

\begin{tabular}{|c|c|c|c|c|c|c|c|c|c|c|}
\hline \multirow[b]{2}{*}{ Fatty acid } & \multicolumn{5}{|c|}{ Breast muscle } & \multicolumn{5}{|c|}{ Leg muscle } \\
\hline & $\mathbf{E}$ & A & $\mathrm{B}$ & $\mathrm{C}$ & $\mathrm{D}$ & $\mathrm{E}$ & A & B & $\mathrm{C}$ & $\mathrm{D}$ \\
\hline \multicolumn{11}{|c|}{ Major constituents $(>2 \%)$} \\
\hline I6:A & $9 \cdot \mathbf{I}$ & $7 \cdot 8$ & $9 \cdot 0$ & $8 \cdot 2$ & IO'I & $7 \cdot 1$ & $9 * 7$ & $9 \cdot 4$ & $8 \cdot 5$ & $9 \cdot 4$ \\
\hline $16: 0$ & $43 \cdot 2$ & $43^{\cdot 1}$ & $43 \cdot 8$ & $44^{\cdot} \cdot 1$ & 44.8 & $42 \cdot 1$ & 40.9 & 40.7 & $40 \cdot 9$ & 40.8 \\
\hline 18:0 & $2 I \cdot I$ & $22 \cdot 4$ & $21 \cdot 9$ & $21 \cdot 3$ & $2 \mathrm{I} \cdot 2$ & $22 \cdot 9$ & 23.7 & 23.0 & $25^{\circ} 0$ & 22.0 \\
\hline $18: 1$ & I $4 \cdot \mathrm{I}$ & I3.9 & I I·3 & $\mathrm{I} 2 \cdot 2$ & $9 \cdot 5$ & $14 \cdot 3$ & $12 \cdot 9$ & I $2 \cdot 1$ & I I.8 & I I 8 \\
\hline $18: 2$ & $6 \cdot 1$ & $5 \cdot 5$ & $3 \cdot 5$ & $4 \cdot 2$ & $2 \cdot 5$ & $6 \cdot 7$ & $5 \cdot 3$ & $4 \cdot 4$ & $3 \cdot 6$ & $3 \cdot 1$ \\
\hline \multicolumn{11}{|c|}{ Minor constituents $(<2 \%)$} \\
\hline $12: 0$ & 0.2 & 0.3 & 0.3 & 0.5 & 0.2 & 0.3 & 0.4 & 0.3 & 0.3 & 0.5 \\
\hline $14: 0$ & 0.4 & 0.4 & 0.7 & 0.8 & $I \cdot O$ & 0.7 & 0.8 & 0.8 & 0.6 & $I \cdot I$ \\
\hline $15: 0$ & 0.3 & 0.2 & 0.2 & 0.2 & 0.3 & 0.3 & 0.4 & 0.2 & 0.3 & 0.5 \\
\hline I6:1 & $I \cdot 2$ & $I \cdot I$ & $\mathbf{I} \cdot \mathbf{I}$ & 0.9 & 0.9 & $x \cdot 7$ & $I \cdot I$ & $I \cdot I$ & $I \cdot I$ & $1 \cdot 2$ \\
\hline $17: 0$ & $I \cdot 2$ & $I \cdot 0$ & $I \cdot 2$ & $I \cdot 3$ & $I \cdot 4$ & 0.8 & $I \cdot 3$ & $I \cdot O$ & $1 \cdot 0$ & $I \cdot I$ \\
\hline $18: 3$ & 0.3 & 0.5 & 0.9 & 0.9 & $I \cdot I$ & $\operatorname{Tr}$ & 0.4 & 0.4 & 0.5 & I'3 \\
\hline $20: 3 \omega 9$ & $1 \cdot 7$ & $1 \cdot 9$ & $I \cdot 6$ & $I \cdot 4$ & $1 \cdot 7$ & I.9 & $2 \cdot 0$ & $\mathrm{I} \cdot 6$ & $2 \cdot 0$ & $1 \cdot 4$ \\
\hline $20: 4$ & $\mathrm{I} \cdot 5$ & $1 \cdot 8$ & 0.8 & $I \cdot O$ & 0.9 & $I \cdot 4$ & I. 5 & 0.8 & 0.8 & 0.9 \\
\hline $20: 5$ & - & 一 & $I \cdot 6$ & $I \cdot 5$ & $x \cdot 9$ & - & - & $I \cdot 7$ & $x \cdot 6$ & 2.0 \\
\hline $22: 5^{\omega} 3$ & - & 一 & I.O & $I=0$ & $I \cdot 2$ & - & - & $1 \cdot 2$ & $I \cdot I$ & $I \cdot 4$ \\
\hline $22: 6$ & - & - & $I \cdot 0$ & $I \cdot O$ & $1 \cdot 6$ & - & - & $I \cdot I$ & $1 \cdot 0$ & $I \cdot 6$ \\
\hline Total saturated & 76 & 75 & 77 & 76 & 79 & 74 & 77 & 75 & 77 & 75 \\
\hline Total monoene & I 5 & 15 & 12 & I3 & Io & 16 & 14 & 13 & I3 & 13 \\
\hline Total diene & 6 & 6 & 4 & 4 & 3 & 7 & 5 & 4 & 4 & 3 \\
\hline Total polyene & 3 & 4 & 7 & 7 & 8 & 3 & 4 & 7 & 7 & 8 \\
\hline
\end{tabular}

Comparison of the compositions of all the muscle lipid fractions from birds raised on diets $\mathrm{B}$ and $\mathrm{C}$, however, discloses no differences in fatty-acid pattern that are not within the experimental error of the analyses. It would appear therefore that EMQ does not influence fatty-acid synthesis or deposition, an observation analogous to that of Walker \& Kummerow (1963) who found no effect of dietary vitamin E on the fatty-acid composition of blood lipids. EMQ therefore probably exerts its protective effect by antioxidant action, either directly by deposition of traces of the antioxidant itself in the tissues (which would be difficult to detect chemically) or by protection of and consequently increased deposition of dietary tocopherol. Some, though not conclusive, evidence in favour of the latter mechanism has already been presented (Neudoerffer \& Lea, 1966a).

Lipids from breast and leg. Leg muscle contained more lipid than breast muscle, the excess being mainly triglyceride (Neudoerffer \& Lea, in preparation), but the composi- 
tion of individual fractions from the two regions showed only the slight differences already referred to in the sections on individual lipids. When such differences were present in the birds on the basal diet (group E) they were frequently detectable also when dietary supplements of beef fat or fish oil had been given.

Compositions of individual lipid fractions. The fatty-acid compositions of the individual lipid fractions from the basal diet group (E) varied widely, each with its own

Table 13. Action of phospholipase $A$ of Crotalus adamanteus on muscle phosphatidylcholine $(P C)$ and phosphatidylethanolamine $(P E)$ of turkeys receiving diets $E$ (control) and $A, B$ and $D^{*}$ : compositions of the lyso compound formed and of the free fatty acids $(F F A)$ liberated $\uparrow$

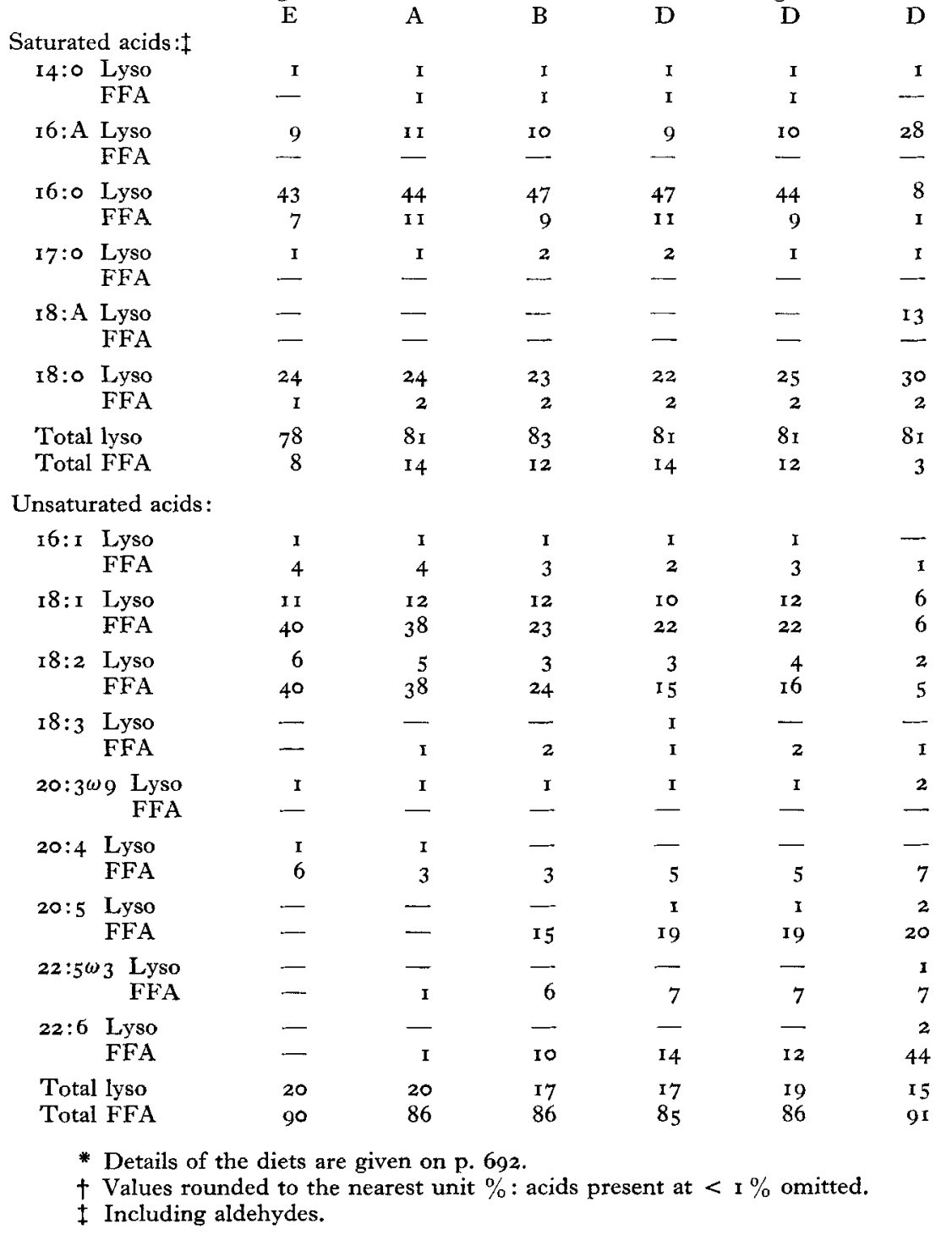


particular pattern, ranging, for example, from SP with $<2 \%$ of acids with two or more double bonds to PI with $37-42 \%$ and PE with $43-45 \%$. Among individual acids, arachidonic (20:4), present only in traces in the triglycerides and cholesterol esters, was slightly higher in the diglycerides $(4-5 \%)$ and free fatty acids $(6-8 \%)$ : in the phospholipids it was low in PC $(2-3 \%)$ and PS $(4 \%)$, higher in $\mathrm{PE}(13-16 \%)$ and PI $(21-23 \%)$. Stearic acid (18:0), present at about $5 \%$ in the triglycerides and cholesterol esters, reached $10-11 \%$ in the free fatty acids and diglycerides, $11-13 \%$ in $\mathrm{PC}, 15-18 \%$ in PE and $20-22 \%$ in SP. PS at $32-34 \%$ and PI at $40-43 \%$ were very rich in stearic acid, and correspondingly low in palmitic, despite the fact that the dietary lipid never contained less than twice as much palmitic as stearic and, in group $D$, contained five times as much. Palmitic acid $(x 6: 0)$, which occurred at levels in the region of $20-30 \%$ in all the 'neutral' lipid fractions, as well as in PC and SP, was reduced to about $10 \%$ in PS and to about $5 \%$ in PE and PI.

Effects of dietary beef fat. Although the beef fat included at the $2.5 \%$ level in diet A had a very different composition from the $2.3 \%$ lipid already present in the basal diet, particularly in its higher stearic and oleic and very much lower linoleic acid content $(43.2 \%$ as compared with $2.9 \%)$, its use caused surprisingly little change in the composition of the muscle lipid fractions. The stearic to palmitic and oleic to palmitoleic ratios were increased in the triglycerides of the skin and muscle lipids, but the phospholipids, apparently more rigorous in their requirements, were little affected. In this, as in other respects, the behaviour of the diglyceride and free fatty-acid fractions appeared to be between the two, and perhaps closer to the phospholipids than to the triglycerides.

The linoleic acid contents of most of the muscle lipid fractions were depressed by beef fat, but the effect was usually small and always much less than the $2:$ I reduction in the concentration of this acid in the dietary lipid. The apparent tenacity with which linoleic acid was retained by the muscle lipids may perhaps be associated with the fact that the level of this essential fatty acid in the basal diet was only $\mathrm{I} \%$ on a weight basis which is not much higher than a recent estimate for the minimal requirements of the chick ( $2 \%$ of dietary calories; Hill, 1966).

Effects of dietary fish oil. Although the fatty acids of beef fat, consisting mainly of saturated and mono-unsaturated acids in almost equal proportions, displaced comparatively little linoleic acid from the muscle lipids, the polyunsaturated acids of the fish oil extensively displaced arachidonic, linoleic, oleic and, when present, eicosatrienoic $(20: 3 \omega 9)$ as well.

The appearance of as much as $8 \%$ of the last-named acid (a metabolite of oleic acid, considered to be indicative of essential fatty-acid deficiency; Hill, I966) in the PI fraction from birds receiving diets $\mathrm{E}$ and $\mathrm{A}$, but not in the corresponding fractions from the birds given fish oil, suggests that, for this phospholipid fraction, the fish-oil polyunsaturates were serving as a satisfactory replacement or supplement for arachidonic acid. In PE, where the fish-oil acids of the $\omega_{3}$ series were obviously displacing arachidonic, the deficiency acid $20: 3 \omega 9$ appeared in appreciable quantity only in the birds receiving no fish oil (groups $\mathrm{E}$ and $\mathrm{A}$ ).

In a number of fractions, exemplified by $\mathrm{PE}$, where arachidonate was already largely 
displaced at the $2.5 \%$ fish-oil level, $5 \%$ fish oil produced little or no further loss, or even a slight recovery. This levelling off in arachidonate displacement might be due either to a balance between transference and displacement (the fish oil itself contained $2 \cdot 2 \%$ arachidonate) or, possibly, to the existence of a lower limit below which arachidonate is less easily displaced.

All these observations are in general agreement with the findings of Mohrhauer \& Holman ( 1963 ) who concluded, on the basis of total (unfractionated) lipid analysis, that dietary linolenate $\left(18: 3^{\omega} 3\right)$ can cause displacement of $20: 3 \omega 9$ and $20: 4 \omega 6$,

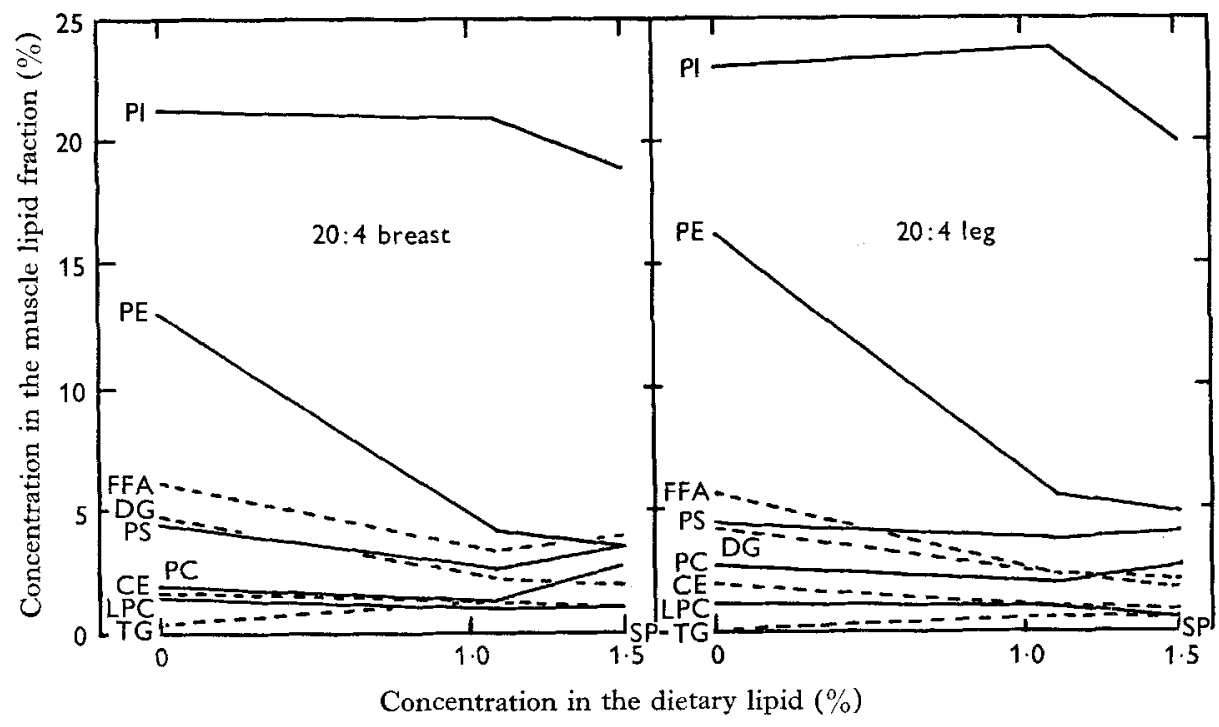

Fig. I. Relation between the concentration of arachidonic acid in the dietary lipid and in the lipid fractions of turkey muscle. TG, triglycerides; DG, diglycerides; FFA, free fatty acids; CE, cholesterol esters; PC, phosphatidylcholine; PE, phosphatidylethanolamine; PS, phosphatidylserine; PI, phosphatidylinositol; LPC, lysophosphatidylcholine; SP, sphingomyelin.

followed by $18: 2$ and $18: 1$ from tissue lipids. They also found that the linolenate metabolites 20:5, 22:5 and 22:6 (all $\omega_{3}$ ) can be incorporated into lipids in place of arachidonate, without apparent toxicity. Lees \& Korn ( 1966 ) similarly showed that fatty acids of the $\omega_{3}$ series can safely replace $\omega 6$ acids in protozoa.

This accepted displacement pattern, however, was not followed in the PI fraction of the turkey muscle lipids, where deposition of the $\omega_{3}$ fish-oil polyunsaturated acids occurred first at the expense of $20: 3 \omega 9, \mathbf{r} 8: 2$ and $\mathrm{I} 8: \mathrm{I}$. Only when as much as $5 \%$ of fish oil was given did the arachidonate content of this lipid fall, and then only slightly (Fig. I).

It is of interest to note the appearance, particularly in PS, of the $22: 5 \omega 6$ acid, a higher member of the arachidonic series which is known to be able to substitute for arachidonic in the prevention of EFA deficiency (Verdino, Blank, Privett \& Lundberg, 1964). This acid was not detected in any of the dietary lipids, but it could have arisen by further desaturation of dietary 22:4 $1 \omega 6$ (Lundberg, 1965). 


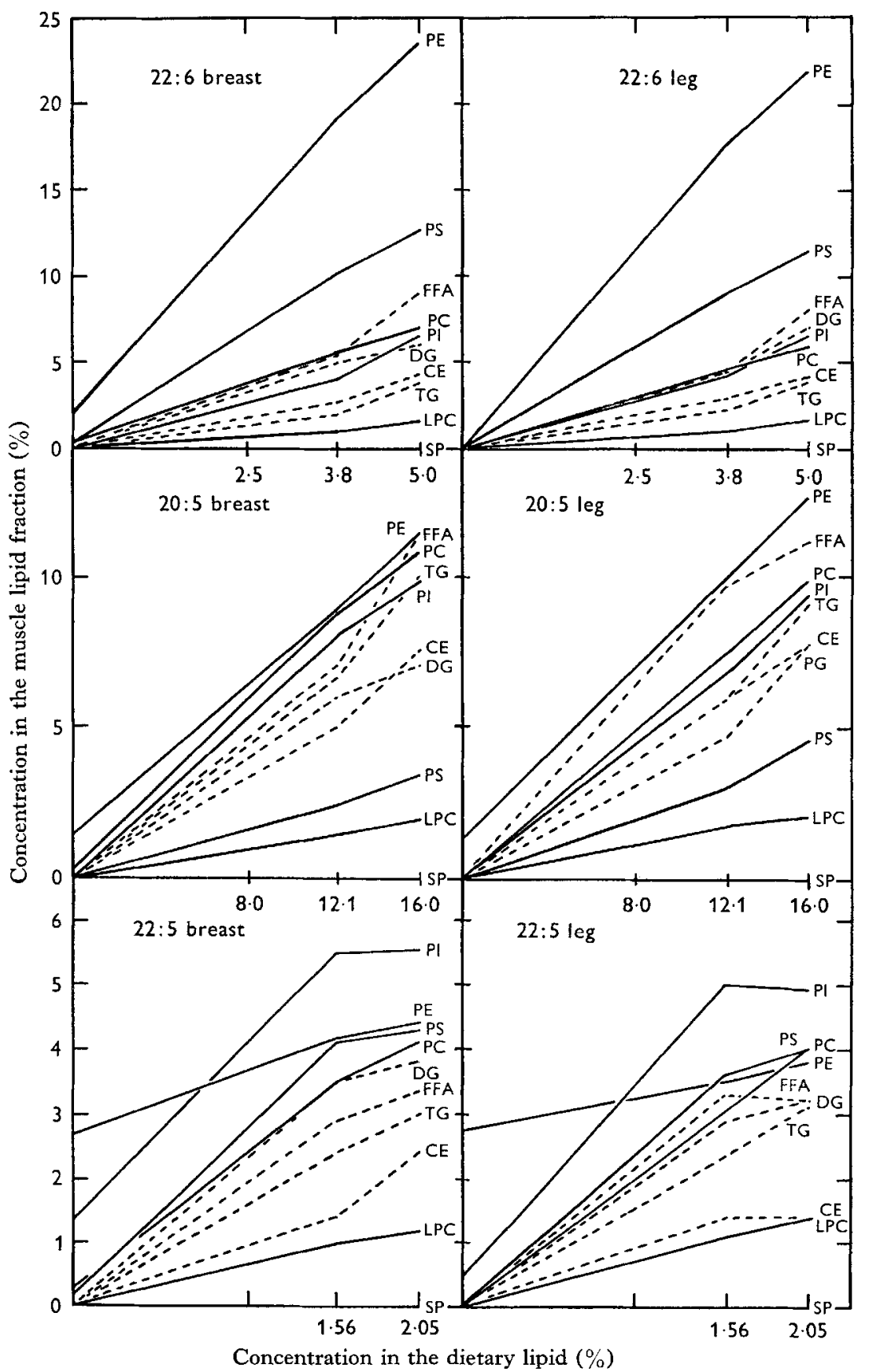

Fig. 2. Relation between the concentrations of three polyunsaturated fatty acids in the dietary lipid and in the lipid fractions of turkey muscle. Abbreviations as in Fig. $I$. 
Quantitative relationships. The concentrations of eight of the fish-oil fatty acids included in diets B, C and D are given in Table 14 , and Fig. 2 shows the extent to which three of the most abundant of these acids appeared in the lipid fractions of the muscle.

All the muscle fractions, except sphingomyelin, incorporated some of the fish-oil acids but, quantitatively, the patterns were very different. PE incorporated 22:6 to a higher degree than any other fraction, with PS next, whereas 22:5 reached its highest level in PI. In most instances the relation between the concentration of a particular acid in the dietary lipid and the level at which it appeared in an individual fraction of the muscle lipid was approximately linear. Where breast and leg plots deviate from linearity in opposite directions, and particularly where the concentrations are low (as with acid 22: 5 in the $\mathrm{CE}$ fraction) the discrepancy might be due to experimental error. However, deposition of acid 22:5 in PI had apparently already reached its maximum at the lower level of dietary fish oil, and in a few instances there were signs of a falling off in other fractions also.

Table 14. Concentrations of eight characteristic fish-oil fatty acids in the diets and in the dietary lipids

\begin{tabular}{|c|c|c|c|c|}
\hline \multirow[b]{2}{*}{$\begin{array}{l}\text { Fatty } \\
\text { acid }\end{array}$} & \multicolumn{2}{|c|}{$\begin{array}{c}\text { Diets } \mathrm{B} \text { and } \mathrm{C}(2.5 \% \text { fish oil, } \\
4.8 \% \text { total lipid })\end{array}$} & \multicolumn{2}{|c|}{$\begin{array}{l}\text { Diet } \mathrm{D} \text { ( } 5.0 \% \text { fish oil, } \\
7.3 \% \text { total lipid })\end{array}$} \\
\hline & $\begin{array}{l}\text { As } \% \\
\text { diet }\end{array}$ & $\begin{array}{c}\text { As \% } \\
\text { dietary lipid }\end{array}$ & $\begin{array}{c}\text { As } \% \\
\text { diet }\end{array}$ & $\begin{array}{c}\text { As \% } \\
\text { dietary lipic }\end{array}$ \\
\hline $16: 2$ & 0.052 & 1.09 & 0.105 & $\mathrm{I} \cdot 43$ \\
\hline $16: 3$ & 0.050 & I.04 & 0.100 & $\mathrm{r} \cdot 37$ \\
\hline $18: 4$ & 0.075 & I. 56 & 0.150 & 2.05 \\
\hline $20: 1$ & 0.052 & 1.09 & 0.105 & $x \cdot 44$ \\
\hline $20: 4$ & 0.055 & I. 15 & 0.110 & $\mathrm{I} \cdot 5 \mathrm{I}$ \\
\hline $20: 5$ & 0.585 & 12.19 & 0.170 & 16.02 \\
\hline $22: 5$ & 0.075 & $\mathrm{I} \cdot 56$ & 0.150 & 2.05 \\
\hline $22: 6$ & 0.182 & 3.80 & $0.3^{65}$ & 5.00 \\
\hline
\end{tabular}

Acid 22:6 appeared among the fatty acids of the PE fraction at a level nearly five times higher than its concentration in the dietary lipid. Since virtually all of this acid enters the molecule in the 2-position, this implies a concentration from the dietary fatty-acid pool of nearly ten times. For triglyceride and LPC the ratios were only about 0.8 and 0.4 . For acid 20:5 the range of ratios was from 0.75 for $\mathrm{PE}$ down to 0.15 for LPC, and for acid 22:5 from 2.5-3 for PI down to < I for CE and LPC. For sphingomyelin the ratios for all the acids were, of course, zero.

Despite the addition of beef fat $(2 \cdot 5 \%, 50 \%$ saturated acids) or anchovy oil $(2 \cdot 5 \%$ or $5.0 \%, 25 \%$ saturated acids) to the basal diet ( $2.3 \%$ lipids, $30 \%$ saturated acids) the proportion of saturated acids in the major glycerophospholipids fractions remained virtually constant at just below one molecule of saturated acid per molecule of lipid, the average (\% by weight) of the ten values being for $\mathrm{PC}_{4} 6 \pm \mathrm{r}$, for $\mathrm{PE} 44 \pm \mathrm{r}$, for PS $46 \pm \mathrm{I}$ and for PI $48 \pm 2$. LPC and SP remained equally unaffected, but at the much higher saturated acid levels of $76 \pm \mathrm{I}$ and $80 \pm \mathrm{I}$ respectively. The corresponding values for the 'neutral' lipid fractions were mostly rather lower and their range a little wider: 
TG $40 \pm 2, \mathrm{FFA}_{3} 8 \pm 5, \mathrm{DG} 43 \pm 6, \mathrm{CE} 42 \pm 3$ and lipid $X 5^{\circ} \pm 2$. This variation of saturated acids over only a narrow range under the influence of marked changes in dietary fatty acids is consistent with the recent findings of Mohrhauer \& Holman (1963) and of Garcia \& Holman (1965).

In general, the observations made in the present investigation lend support to the speculation of Van Deenen ( 1966 ) that a mechanism exists to preserve within definite limits fatty-acid combinations which lend particular properties to phospholipids. The reasons why individual component lipids of muscle build into themselves the particular fatty acids they do, and the wide differences in the extent to which these acids can be altered by changes in the dietary lipid, may well be associated with the physicochemical functions of each lipid, particularly in membrane structures in the cell. Though little seems to be known in this field, instances are beginning to be reported where not only a particular species of phospholipids but also a particular type of fatty-acid composition is being found to be specifically required, as in the recent work of Rothfield \& Pearlman (1966) on the role of cell envelope phospholipid in the enzymic synthesis of bacterial lipopolysaccharide.

Fatty-acid distribution in the glycerophospholipids. The fatty acids split off from the PC and PE fractions of the muscle phospholipids by the venom enzyme contained nearly $90 \%$ unsaturated acids, whereas the acids remaining combined in the residual lyso compounds were about $80 \%$ saturated (Table $\mathrm{r}_{4}$ ). Mono-unsaturated acids were distributed between the acids removed by the enzyme and those remaining in the lyso compounds in a ratio of about $3: 1$; for linoleic acid the ratio was about $6: 1$. Polyenes were almost exclusively concentrated in the free fatty acids.

Since venom phospholipase $A$ is believed to attack specifically the 2-position (of plasmalogens as well as of diacyl phospholipids; Rapport \& Franzl, 1957) these results confirm a strong preference for this position to be occupied by unsaturated (and particularly by polyunsaturated) acids, and for the I-position to be occupied largely by saturated acids (and aldehydes, in the plasmalogens).

Acyl migration from the I- to an already liberated 2-position, followed by hydrolysis could, conceivably, account for the observed $3-14 \%$ of saturated acids found among the free acids liberated, but the presence of $13-19 \%$ of unsaturated acids in the lyso compounds must indicate either incomplete segregation according to position in the molecule or, less likely, incomplete selectivity of the enzyme.

With muscle lecithins from three species of fish Menzel \& Olcott (1964) found only 4-9\% of saturated fatty acids among those split off by Crotalus adamanteus venom, but two of these very highly unsaturated lecithins also contained over $60 \%$ unsaturated acids in the normally mainly saturated I-position, i.e. in the residual lysolecithin. Egg yolk and rat liver lecithins, on the other hand, contained only $14 \%$ and $18 \%$ unsaturated acids in the I-position, proportions similar to those found in our turkey muscle glycerophospholipids.

It would appear, therefore, that the selection of unsaturated fatty acids for the 2-position is considerably more rigorous than of saturated acids for the I-position, but that neither is absolute.

Lysophospholipids, diglycerides and free fatty acids. Some doubt must be felt re- 
garding the origin of the FFA, DG and LPC fractions since these could obviously arise either as intermediate products in the synthesis or metabolism of triglycerides and phospholipids or, in part, by the action of lipolytic enzymes post mortem, despite precautions taken to minimize such action.

Diglycerides, rather than lysophospholipids, are believed to be on the main synthetic pathway to $\mathrm{PC}$ and $\mathrm{PE}$, but some interchange relationship is nevertheless likely between the lyso and the diacyl compounds, and a general similarity in fatty-acid composition is, in fact, found between LPC as isolated from the muscle and as produced by the action of the venom enzyme on PC. Both contain exceptionally high proportions of saturated acids $(74-79 \%$ and $78-83 \%)$, moderate amounts of monoene (10-16\% and $\mathrm{I} 1-\mathrm{I} 3 \%$ ) and small amounts of diene $(3-7 \%$ and $2-6 \%$ ) and, although slightly higher polyene contents were found in LPC as isolated from the tissue, the difference probably does not exceed the possible error in the preparation and analyses of these two fractions: autoxidative losses during the second chromatographic separation of the products of enzymic hydrolysis, for example, would affect the polyunsaturated acids selectively. However, the presence of 2-acyl- as well as of the more usual I-acyl-lysophosphatidylcholine has been reported in tissues (Van Deenen \& de Haas, 1966).

Free fatty acids and diglycerides could be related by synthesis or autolysis to both triglycerides and phospholipids and their compositions do, in fact, suggest such a dual relationship.

The authors are indebted to Dr K. J. Carpenter and the Cambridge University School of Agriculture for advice on and facilities for rearing the turkeys.

\section{REFERENCES}

Bowyer, D. E., Leat, W. M. F., Howard, A. N. \& Gresham, G. A. (1963). Biochim. biophys. Acta 7o, 423.

Dam, H. \& Søndergaard, E. (1964). Z. Ernähr. Wiss. 5, 73.

Fry, J. L., van Walleghem, P., Waldroup, P. W. \& Harms, R. H. (ro65). Poult. Sci. 44, Ior6.

Garcia, P. T. \& Holman, R. T. (I965). F. Am. Oil Chem. Soc. 42, I 137.

Hardin, J. O., Milligan, J. L. \& Sidwell, V. D. (1964). Poult. Sci. 43, 858.

Hill, E. G. ( т 966). F. Nutr. 89, 465 .

Keenan, R. W. \& Hokin, L. E. (1964). Biochim. biophys. Acta 84, 485.

Kerr, S. E. \& Read, W. W. C. (I963). Biochim biophys. Acta 70, 477.

Lea, C. H. (1956). In Biochemical Problems of Lipids, p. 81. [G. Popjak and E. LeBreton, editors.] London: Butterworth.

Lea, C. H., Parr, L. J., L'Estrange, J. L. \& Carpenter, K. J. (Ig66). Br. F. Nutr. 20, Iz3.

Lees, A. M. \& Korn, E. D. (1966). Biochemistry 5, 1475.

Leveille, G. A. \& Sauberlich, H. E. (1963). Proc. Soc. exp. Biol. Med. r12, 300.

Leveille, G. A. \& Sauberlich, H. E. (1964). Proc. Soc. exp. Biol. Med. r17, 653.

Lundberg, W. O. (1965). Chemy Ind. p. 572.

Machlin, L. J. \& Gordon, R. S. (I961). Э. Nutr. 75, 157.

Malins, D. C. \& Mangold, H. K. (1960). F. Am. Oil Chem. Soc. 37, 576.

Marion, J. E. (1965). F. Nutr. 85, 38 .

Marion, J. E. \& Woodroof, J. G. (1963). Poult. Sci. 42, r 202.

Marion, J. E. \& Woodroof, J. G. (1965). F. Fd Sci. 30, 38.

Marion, J. E. \& Woodroof, J. G. (r966). Poult. Sci. 45, 24 I.

McKibbins, S. W., Harris, J. F. \& Saeman, J. F. (196r). F. Chromat. 5, 207.

Menzel, D. B. \& Olcott, H. S. (1964). Biochim. biophys. Acta 84, 133.

Mickelberry, W. C., Rogler, J. C. \& Stadelman, W. J. (I966). Poult. Sci. 45, 3 I3. 
Miller, D., Leong, K. C., Knobl, G. M. Jr \& Gruger, E. H. Jr (1964). Proc. Soc. exp. Biol. Med. r16, 1147.

Miller, D., Leong, K. C., Knobl, G. M. Jr \& Gruger, E. H. Jr (1965). Poult. Sci. 44, I072.

Mohthauer, H. \& Holman, R. T. (I963). F. Nutr. 81, 67.

Neudoerffer, T. S. \& Lea, C. H. (1966a). Br. F. Nutr. 20, 58I.

Neudoerffer, T. S. \& Lea, C. H. (I966b). F. Chromat. 21, I38.

O'Brien, J. S., Fillerup, D. L. \& Mead, J. F. (1964). F. Lipid Res. 5, 329.

Parker, F. \& Peterson, N. F. (1965). F. Lipid Res. 6, 455.

Peng, C. Y. \& Dugan, L. R. Jr (1965). F. Am. Oil Chem. Soc. 42, 533.

Rapport, M. M. \& Franzl, R. E. (1957). 7. biol. Chem. 225, 85 I.

Rothfield, L. \& Pearlman, M. (1966). F. biol. Chem. 241, 1386.

Sgoutas, D. (1966). Can. F. Biochem. Physiol. 44, 763 .

Shapiro, I. L. \& Kritchevsky, D. (1965). F. Chromat. 18, 599.

Skipski, V. P., Peterson, R. F. \& Barclay, M. (1962). F. Lipid Res. 3, 467.

Skipski, V. P., Peterson, R. F. \& Barclay, M. (1 964). Biochem. F. 9o, 374.

Van Deenen, L. L. M. (1966). F. Am. Oil Chem. Soc. 43, 296.

Van Deenen, L. L. M. \& de Haas, G. H. (1966). A. Rev. Biochem. 35, (1), I57.

Verdino, B., Blank, M. L., Privett, O. S. \& Lundberg, W. O. (I g64). F. Nutr. 83, 234.

Walker, B. L. \& Kummerow, F. A. (1963). F. Nutr. 81, 75.

Winter, E. (1963). Z. Lebensmittelunters. u. -Forsch. 123, 205. 